Article

\title{
Development of Multifunctional Cosmetic Cream Using Bioactive Materials from Streptomyces sp. T65 with Synthesized Mesoporous Silica Particles SBA-15
}

\author{
Ram Hari Dahal ${ }^{1} \mathbb{D}$, Tuan Manh Nguyen ${ }^{1,2}$, Dong Seop Shim ${ }^{3}$, Joon Young Kim ${ }^{4}$, Jangyul Lee ${ }^{4}$ \\ and Jaisoo Kim ${ }^{1, *}$ \\ 1 Department of Life Science, College of Natural Sciences, Kyonggi University, Suwon, Gyeonggi-Do 16227, \\ Korea; ramhari.dahal@gmail.com (R.H.D.); tuannm@tnu.edu.vn (T.M.N.) \\ 2 Institute of Life Sciences, Thai Nguyen University of Agriculture and Forestry, Quyet Thang, \\ Thai Nguyen 250-000, Vietnam \\ 3 Innogene, Co., \#301 Woolim E-biz Center1, 28, Digital-ro 33-gil, Guro-gu, Seoul 08337, Korea; \\ dshim@innogene.com \\ 4 Gyeonggi Small \& Medium Business Growth Accelerating Center, 304ho, Suseong-ro 8, Gwonseon-gu, \\ Suwon 16426, Korea; ooridle@gmail.com (J.Y.K.); zzangbaw@hanmail.net (J.L.) \\ * Correspondence: jkimtamu@kgu.ac.kr
}

Received: 26 February 2020; Accepted: 23 March 2020; Published: 26 March 2020

\begin{abstract}
Various cosmetics having a single function are increasingly being used, but cosmetics having multifunctional activities remain limited. We aimed to develop a multifunctional cosmetic cream having antioxidant, anti-tyrosinase, anti-aging and antimicrobial activities. Antimicrobial activities were performed by disc-diffusion method. Cell toxicity and cell proliferations were evaluated in a 96-well plate with different cell lines such as HaCaT, RAW264.7, CCD-986Sk, B16F1, and B16F10. Mushroom tyrosinase inhibition, elastase inhibition, and 1,1-diphenyl-2-picrylhydrazyl (DPPH) radical scavenging activities were evaluated and $\mathrm{IC}_{50}$ was calculated. Mesoporous silica particle was synthesized using Pluronic P123 and tetraethyl ortho-silicate (TEOS). Facial pictures were captured by VISIA-CR (Facial Imaging System for Clinical Research). Roughness of image was analysed by PRIMOS software and brightness of image was analyzed by Chromameter CR- 400 . The crude product of strain T65 inhibited the different human pathogenic bacteria such as Bacillus subtilis, Escherichia coli, Propionibacterium acnes, Staphylococcus aureus, Pseudomonas aeruginosa, and Staphylococcus epidermidis. The $\mathrm{IC}_{50}$ of $\mathrm{T} 65$ crude product for mushroom tyrosinase, elastase, and DPPH radical scavenging activities were $58.73,14.68$, and $6.31 \mu \mathrm{g} / \mathrm{mL}$, respectively. T65 crude product proliferated collagen type I in CCD-986Sk cell up to $145.91 \% \pm 9.11 \%$ (mean \pm SD; mean of 24 , 48 , and $72 \mathrm{~h}$ ) at $250 \mathrm{pg} / \mathrm{mL}$. Synthesized mesoporous particles (SBA-15) confirmed the sustainable performance by control-release for three days. Formulated functional cosmetic cream containing T65 embedded SBA-15, significantly decreased the skin roughness by $4.670 \%$ and increased the skin brightness by $0.472 \%$ after application of 4 weeks. T65 crude product inhibited both Gram-positive and Gram-negative pathogens. Synthesized mesoporous particle, SBA-15, confirmed the physiologically active substance was released in sustainable release condition. T65 crude product showed impeccable antimicrobial, antioxidant, anti-aging, and whitening activities with non-cytotoxic effects to different cell lines related to the human skin.
\end{abstract}

Keywords: antioxidant; cytotoxicity; anti-tyrosinase; anti-aging; antimicrobial; mesoporous silica particles; cosmeceutical formulations; aesthetic application 


\section{Introduction}

The skin is the largest organ and outer covering of the human body. The visual appearance of the skin allows for estimation of age, gender, health, attractiveness, and beauty [1,2]. Cosmetic products are extensively used for enhancing the appearance of the skin and to reduce skin aging. In addition, topical application of cosmetics demonstrates how to increase attractiveness by manipulating factors of beauty associated with facial contrast [3,4]. Cosmetic industries are constantly searching for novel and natural bioactive materials with anti-aging, antioxidant, anti-tyrosinase, and antimicrobial properties for cosmeceutical formulations to improve skincare approaches $[5,6]$.

Skin aging is a complex biological process caused by various intrinsic and extrinsic factors that lead to physiological dysfunction and loss of the structural integrity of the skin. Intrinsic aging, generally known as natural aging (chronologic aging) of the skin is related to hormonal changes based on age, whereas extrinsic aging is associated with movement of the muscle, pollution, nicotine, exposure to solar radiation, caffeine, temperature, lifestyle such as diet (nutrition), lack of sleep, stress, and other health conditions [7-9]. Elastin helps skin to return to its original position after movement, whereas elastase produced in acinar cells degrades the elastin and leads to skin aging [9]. Anti-elastase inhibits the elastase and retains elastin in its initial status, which prevents skin from aging. Cosmetic or skin care products with anti-aging properties positively affect skin aging [10-13].

Free radicals are usually generated during cellular metabolism. Reactive oxygen species (ROS) and reactive nitrogen species (RNS), such as anion radical, superoxide, peroxide, hydroxyl radical, nitric oxide (NO), peroxynitrile, and hypochlorous acid are responsible for oxidative damage to the cells, lipids, proteins, and DNA, leading to atherosclerosis, carcinogenesis, cardiovascular diseases, cellular aging, chronic inflammation, diabetes, hypertension, mutagenesis, neurodegenerations, rheumatoid arthritis, stroke, septic shock, and other degenerative diseases [7,14-17]. Antioxidants prevent oxidation of proteins and generation of ROS and RNS that may reduce free-radical damage to normal tissues by combating oxidative stress [17-19].

The skin produces a dark pigment known as melanin. The production of melanin prevents the skin from UV-induced damage [9]. However, overproduction and accumulation of melanin cause cutaneous hyperpigmentation, leading to esthetic complications such as melasma, freckles, senile lentigines, nevus, and ephelis $[9,20]$. Tyrosinase is a glycoprotein found in the membranes of melanosomes that are responsible for melanin biosynthesis by hydroxylation of L-tyrosinase to 3,4-dihydroxyphenylalanine (L-DOPA) and subsequent oxidation of L-DOPA to dopaquinone [21]. Due to the spontaneous polymerization, dopaquinone is finally converted to melanin [22]. Over-produced melanin should be controlled to maintain the skin integrity. That is why the discovery of novel tyrosinase inhibitors for the development of cosmeceutical formulations has received a significant interest [23-25].

Antimicrobial preservatives are added to cosmetic products to maintain the microbiological purity during the entire period of its applications [26]. Instead of using cosmetics preservatives such as methylparabens, natural antimicrobial compounds having other functions are better and more beneficial for human health [27-29]. The secondary metabolites isolated from bacterial resources may have both preservative and antimicrobial properties that inhibit the colonization of bacterial pathogens (Propionibacterium acnes, Staphylococcus epidermidis, and Staphylococcus aureus) in the skin $[9,26,28]$.

Bioactive compounds produced by soil or marine bacteria, especially actinobacteria, are unexploited and still unexplored [23,30]. Various bioactive compounds that are applicable in the cosmeceutical and cosmetic industry, including those with anti-aging, antioxidant, anti-tyrosinase, antimicrobial, and non-cytotoxic properties, have great potential for novel uses.

There are numerous studies on bioactive materials isolated from plants that are currently used in cosmeceutical formulations, but very few studies on bioactive materials from bacteria are available $[9,21,24-27,31]$. This study aimed to evaluate the cosmeceutical potential of ethyl acetate extracts from the bacterial strain Streptomyces sp. T65 for antioxidant, anti-aging, anti-tyrosinase, and antibacterial activities and any cytotoxic effects on different mouse and human cell lines. In addition, we aimed to synthesize mesoporous silica particles. Finally, the main goal of this study was to 
develop the final cosmetic product for topical application using bioactive material extracted from soil microorganisms.

\section{Materials and Methods}

\subsection{Reagents, Cell Lines, and Equipment}

All solvents used were of analytical grade. B16-F10 melanoma cell line, B16-F1 mouse melanoma cell line, and human keratinocyte cell line (HaCaT) were purchased from American Type Culture Collection (ATCC, Manassas, VA, USA). Dulbecco's modified Eagles' medium (DMEM), penicillin-streptomycin, and heat-inactivated fetal bovine serum (HI FBS) were purchased from Gibco (Thermo Fisher Scientific Korea Ltd., Seoul, South Korea). The Cell Counting Kit-8 (CCK-8) was purchased from Dojindo (Kumamoto, Japan). A mouse macrophage cell line RAW264.7 and CCD-986Sk human fibroblasts were purchased from the Korean Cell Line Bank (Seoul, South Korea). Lipopolysaccharide (LPS, Escherichia coli, serotype O11:B4), sulfanilamide, naphthylethylenediamine dihydrochloride, mushroom tyrosinase, porcine pancreatic elastase, L-tyrosine, ascorbic acid, arbutin, $\mathrm{N}$-Succ-(Ala) ${ }_{3}$-p-nitroanilide, 3-(4,5-dimethylthiazol-2-yl)-2,5-diphenyl tetrazolium bromide (MTT), collagen type I, Tween 20, tetramethylbenzidine (TMB), tetraethyl ortho-silicate (TEOS), pluronic P-123 (poly(ethylene glycol)-block-poly(propylene glycol)-block-poly(ethylene glycol); PEG-PPG-PEG), and $\alpha$-melanocyte-stimulating hormone $(\alpha-\mathrm{MSH})$ were purchased from Sigma-Aldrich (St. Louis, MO, USA). 1,1-Diphenyl-2-picrylhydrazyl (DPPH) and oleanolic acid were purchased from Aldrich (St. Louis, MO, USA). COL1A1 (Collagen, type I, alpha 1) primary antibody and secondary antibody conjugated with HRP (Horseradish peroxidase) were purchased from Santa Cruz Biotechnology (Santa Cruz, CA, USA). A SpectraMax 340PC384 Microplate Reader (Molecular Devices, Sunnyvale, CA, USA) was used for 96-well plate reading.

\subsection{Pathogenic Bacterial Strains}

Staphylococcus epidermidis KACC 13234 and Pseudomonas aeruginosa KACC 10185 were purchased from the Korean Agriculture Culture Collection (KACC, Jeonju, South Korea); Bacillus subtilis KEMB 51201-001, Escherichia coli KEMB 212-234, and Staphylococcus aureus KEMB 7301-069 were obtained from the Korea Environmental Microorganisms Bank (KEMB, Suwon South Korea); and Propionibacterium acnes KCTC 3314 was purchased from the Korean Collection for Type Cultures (KCTC, Jeongeup, South Korea).

\subsection{Isolation and Preservation}

Different soil samples were collected from reclaimed grasslands in Hwaseong $\left(37^{\circ} 16^{\prime} 10^{\prime \prime} \mathrm{N}\right.$ $\left.126^{\circ} 45^{\prime} 43^{\prime \prime} \mathrm{E}\right)$, and Kyonggi University forest $\left(37^{\circ} 18^{\prime} 1^{\prime \prime} \mathrm{N} 127^{\circ} 2^{\prime} 20^{\prime \prime} \mathrm{E}\right)$ in Korea. Bacteria were isolated using a method previously described [9]. Colonies were streaked on R2A plates every 1 week for short-term preservation and stored at $-80^{\circ} \mathrm{C}$ as a suspension in R2A broth supplemented with $20 \%$ $(v / v)$ glycerol for long-term preservation.

\subsection{Screening, Identification, and Phylogenetic Position of Isolated Strains}

Screening for cosmetics and antimicrobial activities of isolated strains were completed as previously described [9]. Bacteria having functions were identified using $16 \mathrm{~S}$ rRNA gene sequencing. Genomic DNA of strains was extracted using an InstaGene Matrix kit (Bio-Rad, Hercules, CA, USA), and the 16S rRNA gene was amplified by PCR using the universal bacterial primer 27F and 1492R [32]. The PCR product was purified with a multiscreen-filter plate (Millipore Corp., Bedford, MA, USA), and was sequenced with an Applied Biosystems 3770XL DNA analyzer using a BigDye Terminator cycle sequencing kit v.3.1 (Applied Biosystems, Foster City, CA, USA). A nearly complete sequence was complied with SeqMan software (DNASTAR Inc., Madison, WI, USA). The closest strain of isolated functional strains was identified using EzBioCloud [33] and the NCBI GenBank database [34]. Related 
$16 \mathrm{~S}$ rRNA sequences were obtained from GenBank, and phylogenetic analysis was accomplished using MEGA7 [35].

\subsection{Culture of Bacteria}

P. acnes was cultured by incubation at $37^{\circ} \mathrm{C}$ for 3-4 days anaerobically in Schaedler anaerobe broth (Oxoid). For the anaerobic culture, BBL anaerobic jar with GasPak EZ Gas Generating Container System (Becton Dickinson, NJ, USA) was used. S. epidermidis and S. aureus were cultured in TSB (Tryptic soy broth) medium (Oxoid) at $37^{\circ} \mathrm{C}$ for $24 \mathrm{~h}$ aerobically. E. coli, P. aeruginosa, and B. subtilis were cultured in LB (Luria-Bertani) (Oxoid) medium. Isolated bacterial strains were cultured in R2A at $28^{\circ} \mathrm{C}$ for $4-5$ days.

\subsection{Fermentation}

For the fermentation process, the inoculum was prepared in R2A broth at $28^{\circ} \mathrm{C}$ for $4-5$ days at $150 \mathrm{rpm}$. Strain T65 was fermented using 1-2\% inoculum in ISP2 (International Streptomyces Project 2) medium at $28^{\circ} \mathrm{C}$ for 1 week at $140 \mathrm{rpm}$.

\subsection{Extraction}

The harvested culture broth was centrifuged at $11,305 \times \mathrm{g}$ for $20 \mathrm{~min}$ at $4{ }^{\circ} \mathrm{C}$ with large capacity centrifuge 1736R (LABOGENE, Seoul, Korea). The culture supernatant was filtered with $150 \mathrm{~mm}$ size filter paper (Whatman 1001-150, GE Healthcare, Maidstone, UK) to eliminate cell debris and concentrated with a rotary evaporator at $40^{\circ} \mathrm{C}$. The concentrated crude product was then extracted two times with equal volume using five different solvents ( $n$-hexane, di-ethyl ether, di-chloromethane, chloroform, and ethyl acetate). Ethyl acetate was found to be the best solvent, and further analyses were conducted using ethyl acetate extract. The organic layer was separated by a separation funnel and evaporated to dryness. Finally, the dried crude product was dissolved in methanol for further assessment.

\subsection{Collection of Active Fractions by Preparative HPLC (Prep-HPLC)}

Active fractions of crude culture extract of T65 were collected using preparative HPLC (Agilent 1200 series). Shim-pack-PREP-ODS (K) C18 reverse column $(30 \mathrm{~mm}$ i.d. $\times 25 \mathrm{~cm}$ ) with a $15 \mu \mathrm{m}$ particle size was used as the stationary phase. For the mobile phase, $0.1 \% \mathrm{HCHOOH}$ water (solvent $\mathrm{A}$ ) and acetonitrile (solvent B) were used. Solvent B concentration was $10 \%$ to $100 \%$ from $0 \mathrm{~min}$ to $60 \mathrm{~min}$ and $100 \%$ from $60 \mathrm{~min}$ to $75 \mathrm{~min}$ were used. The flow rate was $15 \mathrm{~mL} / \mathrm{min}$. Multi-wave detector (MWD) was used with 208, 230, 254, and $280 \mathrm{~nm}$. Collected fractions from $14 \mathrm{~min}$ to $21 \mathrm{~min}$ were evaporated to dryness and dissolved in methanol (T65 crude product) for further assessments.

\subsection{Cell Viability of HaCaT Cell}

Cell viability of $\mathrm{HaCaT}$ cells was determined with a CCK-8 (Cell Counting Kit-8) assay according to the manufacturer's instructions. The HaCaT cells were seeded in 96-well plates at $10^{4}$ cells per well and then incubated at $37^{\circ} \mathrm{C}$ for $24 \mathrm{~h}$ in Dulbecco's modified Eagles' medium (DMEM) containing $10 \%$ fetal bovine serum (FBS). Cells were treated with different concentrations of T65 crude product $(10 \mathrm{mg} / \mathrm{mL}, 1 \mathrm{mg} / \mathrm{mL}, 100 \mu \mathrm{g} / \mathrm{mL}, 10 \mu \mathrm{g} / \mathrm{mL}, 1 \mu \mathrm{g} / \mathrm{mL}, 100 \mathrm{ng} / \mathrm{mL}$, and $1 \mathrm{ng} / \mathrm{mL})$, and incubated at room temperature for $2 \mathrm{~h}$ in a humidified atmosphere containing $5 \% \mathrm{CO}_{2}$ with the addition of $10 \mu \mathrm{L}$ of CCK-8 reagent. The absorbance of the reaction mixture was measured with a microplate spectrophotometer at $450 \mathrm{~nm}$ and the percentage of cell viability was calculated. 


\subsection{Evaluation of Antioxidant Activities}

\subsubsection{Evaluation of Toxicity in RAW264.7 Cells}

RAW264.7 cells were maintained in DMEM containing 10\% FBS, $100 \mathrm{U} / \mathrm{mL}$ of penicillin, and $100 \mu \mathrm{g} / \mathrm{mL}$ of streptomycin at $37^{\circ} \mathrm{C}$ in a $5 \% \mathrm{CO}_{2}$ incubator. RAW264.7 cells were seeded in a 96-well flat-bottom microtiter plate at a density of $10^{4}$ cells per well with different concentrations $(0-1 \mathrm{mg} / \mathrm{mL})$ of T65 crude product and incubated at $37^{\circ} \mathrm{C}$ for $24 \mathrm{~h}$ in a $5 \% \mathrm{CO}_{2}$ incubator. After $24 \mathrm{~h}$ incubation, cells were washed twice with phosphate-buffered saline (PBS), and $190 \mu \mathrm{L}$ of fresh medium and $10 \mu \mathrm{L}$ of MTT working solution $(5 \mathrm{mg} / \mathrm{mL})$ were added to each well, and the plate was then incubated at $37^{\circ} \mathrm{C}$ for $4 \mathrm{~h}$ in a $5 \% \mathrm{CO}_{2}$ incubator. Then, the supernatant was removed, and the formazan crystals that formed were solubilized by adding $150 \mu \mathrm{L}$ of DMSO (dimethyl sulfoxide) in each well for $10 \mathrm{~min}$ at $37^{\circ} \mathrm{C}$ in a $5 \% \mathrm{CO}_{2}$ incubator. The intensity of the dissolved formazan crystals was quantified using a microplate reader at $570 \mathrm{~nm}$.

\subsubsection{Nitric Oxide Determination}

The RAW264.7 cells $\left(10^{5}\right.$ cells $\left./ \mathrm{mL}\right)$ were pretreated with various concentrations of T65 crude product $(15.5-125 \mu \mathrm{g} / \mathrm{mL})$ for $30 \mathrm{~min}$, followed by stimulation with $1 \mu \mathrm{g} / \mathrm{mL}$ LPS for $24 \mathrm{~h}$. The concentration of NO released from the cells was determined by Griess reagent using the standard curve of $\mathrm{NO}_{2}^{-}[36]$. One-hundred microliters of culture supernatant was incubated with $100 \mu \mathrm{L}$ of Griess reagent (mixture of N-1-naphthylethylenediamine dihydrochloride (NEDHC) and sulfanilamide) at room temperature for $20 \mathrm{~min}$ in the dark. The absorbance was measured at $540 \mathrm{~nm}$.

\subsubsection{DPPH Free Radical Scavenging Assay}

DPPH free radical scavenging activities were conducted according to a previously described method [9]. The crude product of T65 culture extract was diluted to concentrations 600, 200, 100, 20, and $4 \mu \mathrm{g} / \mathrm{mL}$ in methanol. The reaction mixture of $180 \mu \mathrm{L}$ was made with $90 \mu \mathrm{L}$ of $0.1 \mathrm{mM} \mathrm{DPPH}$ (dissolved in $\mathrm{MeOH}$ ) and $90 \mu \mathrm{L}$ of sample solutions of different concentrations (Table S1). Test reactions were mixed thoroughly in 96-well plates, incubated at $37^{\circ} \mathrm{C}$ for $30 \mathrm{~min}$, and absorption was measured at $516 \mathrm{~nm}$ with a spectrophotometer. The percentage of DPPH inhibition was calculated as follows:

$$
\text { Inhibition }(\%)=\left[1-\frac{(\text { ODexp }- \text { ODcon })}{(\text { ODstd }- \text { ODbln })}\right] \times 100
$$

where ODexp is absorbance of the experimental sample; ODcon is absorbance of the control; ODstd, the absorbance of the standard; and ODbln, the absorbance of the blank.

\subsection{Evaluation of Anti-Aging Activities}

\subsubsection{Evaluation of Cytotoxicity in CCD-986Sk Cells}

Cell cytotoxicity of various concentrations $(0-1 \mathrm{mg} / \mathrm{mL})$ of $\mathrm{T} 65$ crude product in human skin fibroblast cells (CCD-986Sk) was determined by MTT assay as previously described for MTT assay of RAW264.7 cells.

\subsubsection{Human Fibroblast Proliferation Using CCD-986Sk Cells}

Human dermal fibroblast (HDF) cell proliferation was determined in CCD-986Sk cells using a CCK-8 assay. CCD-986Sk cells were seeded in 96-well plates at $5 \times 10^{3}$ cells/well and then incubated at $37^{\circ} \mathrm{C}$ for $24 \mathrm{~h}$ in DMEM containing 10\% FBS. Cells were treated with different concentrations of T65 crude product $(0-1 \mathrm{mg} / \mathrm{mL})$ and incubated at room temperature for $2 \mathrm{~h}$ in a humidified atmosphere containing $5 \% \mathrm{CO}_{2}$ with the addition of $10 \mu \mathrm{L}$ of CCK-8 reagent. The absorbance of the reaction 
mixture was measured with a microplate reader at $450 \mathrm{~nm}$ and the percentage of viable cells was determined in comparison to the absorbance of the untreated cells.

\subsubsection{Collagen Type I Synthesis Assay}

Collagen type I synthesis was assayed by an enzyme-linked immunosorbent assay (ELISA). CCD-986Sk cells were seeded in 96-well plates at a density of $5 \times 10^{3}$ cells/well in DMEM containing $10 \%$ FBS and incubated at $37^{\circ} \mathrm{C}$ for $24 \mathrm{~h}$. Various concentrations of T65 crude product $(31.25-250 \mathrm{pg} / \mathrm{mL})$ was added in FBS-free medium for $24 \mathrm{~h}$. Then, $100 \mu \mathrm{L}$ of culture medium and collagen type I was added into collagen-coated 96-well plates and incubated at $37{ }^{\circ} \mathrm{C}$ for 24,48 , and $72 \mathrm{~h}$. Each well was washed with $0.05 \%$ phosphate-buffered saline with $0.1 \%$ Tween 20 (PBST) and COL1A1 primary antibody was added and incubated for $1 \mathrm{~h}$. Again, the wells were washed with $0.05 \%$ PBST and a secondary antibody conjugated with HRP (horseradish peroxidase) was added and incubated for $1 \mathrm{~h}$. Each well was washed with $0.05 \%$ PBST, and TMB (tetramethylbenzidine) was added. After obtaining the desired color intensity (blue), the reaction was terminated by adding $0.5 \mathrm{~N} \mathrm{H}_{2} \mathrm{SO}_{4}$, which turned the color of the solution yellow. The absorbance was measured at $450 \mathrm{~nm}$ with a microplate reader, and collagen type I production was determined.

\subsubsection{Elastase Inhibition Assay}

Porcine pancreatic elastase (PPE) inhibition activities were assayed according to a procedure previously described [9]. The T65 crude product was diluted to concentrations of 3000, 1000, 500, and $100 \mu \mathrm{g} / \mathrm{mL}$ in methanol. The reaction mixture was prepared with $0.2 \mathrm{M}$ Tris- $\mathrm{HCl}$ buffer $(\mathrm{pH} 8.0)$, $0.5 \mathrm{mM} \mathrm{N}$-Succ-(Ala) $)_{3}-\rho$-nitroanilide (SANA) as a substrate, porcine pancreatic elastase $(3.5 \mathrm{U} / \mathrm{mL}$ in $0.2 \mathrm{M}$ Tris- $\mathrm{HCl}$ buffer; $\mathrm{pH} 8.0$ ), and the inhibitor (sample). Each sample was pre-incubated at $37^{\circ} \mathrm{C}$ for $15 \mathrm{~min}$, and the total reaction mixture was incubated at $37^{\circ} \mathrm{C}$ for $20 \mathrm{~min}$. The absorption was measured at $400 \mathrm{~nm}$. The total reaction mixture of $150 \mu \mathrm{L}$ was prepared as shown in Table S2. The final concentrations of the sample in the reaction mixture were $300,100,50$, and $10 \mu \mathrm{g} / \mathrm{mL}$. The percentage of PPE inhibition was calculated using Formula (1).

\subsection{Evaluation of Whitening Activities}

\subsubsection{Evaluation of Cytotoxicity in B16F1 Cells}

Cytotoxicity of T65 crude product to B16F1 melanoma cells was determined by an MTT assay. B16F1 cells were seeded in 96-well plates at $10^{4}$ cells per well and then incubated at $37^{\circ} \mathrm{C}$ for $24 \mathrm{~h}$ in DMEM containing 10\% FBS. Cells were treated with different concentrations of T65 crude product $(0-1 \mathrm{mg} / \mathrm{mL})$ and incubated at room temperature for $2 \mathrm{~h}$ in a humidified atmosphere containing $5 \%$ $\mathrm{CO}_{2}$. The absorbance of the reaction mixture was measured with a microplate spectrophotometer at $450 \mathrm{~nm}$ and the percentage of cell viability was calculated.

\subsubsection{Melanin Synthesis Inhibition in B16F10 Cells}

B16F10 cells were pretreated with $\alpha$-MSH in 6-well plates at $10^{5}$ cells per well and incubated at $37^{\circ} \mathrm{C}$ for $24 \mathrm{~h}$ in DMEM containing $10 \%$ FBS to promote melanin synthesis. The cells were incubated with various concentrations of T65 crude product $(31.25-125 \mu \mathrm{g} / \mathrm{mL})$ and $100 \mu \mathrm{g} / \mathrm{mL}$ of arbutin as a positive control in the presence or absence of $\alpha$-MSH for $48 \mathrm{~h}$. The melanin synthesis inhibition in B16F10 melanoma cells was observed.

\subsubsection{Mushroom Tyrosinase Inhibition Assay}

Mushroom tyrosinase inhibition activities were determined as previously described [9]. The T65 crude product was diluted to concentrations of $3000,1000,500$, and $100 \mu \mathrm{g} / \mathrm{mL}$ in methanol. The reaction mixture was prepared with $0.1 \mathrm{M}$ potassium phosphate buffer ( $\mathrm{pH} 6.8$ ), $3 \mathrm{mM}$ L-tyrosine solution [dissolved in DW (distilled water)], and $2000 \mathrm{U} / \mathrm{mL}$ mushroom tyrosinase (dissolved in $0.05 \mathrm{M}$ 
potassium phosphate buffer, pH 6.8; Sigma) in 96-well plates. Total test mixture of $150 \mu \mathrm{L}(120 \mu \mathrm{L}$ phosphate buffer, $10 \mu \mathrm{L}$ L-tyrosine, $15 \mu \mathrm{L}$ sample solution, and $5 \mu \mathrm{L}$ mushroom tyrosinase; Table S3) was incubated at $37^{\circ} \mathrm{C}$ for $10 \mathrm{~min}$ and absorption was measured at $475 \mathrm{~nm}$. The final concentrations of the sample in the reaction mixture were 300,100,50, and $10 \mu \mathrm{g} / \mathrm{mL}$. The standard was without the sample solution, the control was without L-tyrosine, and the blank was without L-tyrosine and the sample solution. The percentage of tyrosinase inhibition was calculated by applying Formula (1).

\subsection{Analysis of Amino Acids}

The free amino acid of T65 crude product was determined by the GC-FID (gas chromatography -flame ionization detector) method at the Korea Polymer Testing and Research Institute (Koptri). For the GC-FID method, the machine used was an Agilent 6890N GC-FID; column, ZB-AAA (10 m $\times 0.25 \mathrm{~mm})$; injection part temperature, $250{ }^{\circ} \mathrm{C}$; injection column, $2 \mu \mathrm{L}$; split ratio, 5:1; temperature condition, $110{ }^{\circ} \mathrm{C}$ $\rightarrow 32{ }^{\circ} \mathrm{C} / \mathrm{min} \rightarrow 320^{\circ} \mathrm{C}$; detector, FID @ $320^{\circ} \mathrm{C}$; carrier, nitrogen gas, $1.5 \mathrm{~mL} / \mathrm{min}$; maker, Phenomenex; amino acid standard; and concentration, $200 \mu \mathrm{mol} / \mathrm{L}$.

The composite amino acids of T65 crude product was determined by the GC-FID (gas chromatography-flame ionization detector) method at the Korea Polymer Testing and Research Institute (Koptri). For GC-FID, the machine used was an Agilent 6890N GC-FID; column, ZB-AAA $(10 \mathrm{~m} \times 0.25 \mathrm{~mm})$; injection part temperature, $250^{\circ} \mathrm{C}$; injection column, $2 \mu \mathrm{L}$; split ratio, 5:1; temperature condition, $110{ }^{\circ} \mathrm{C} \rightarrow 32{ }^{\circ} \mathrm{C} / \mathrm{min} \rightarrow 320{ }^{\circ} \mathrm{C}$; detector, FID @ $320{ }^{\circ} \mathrm{C}$; carrier, nitrogen gas, $1.5 \mathrm{~mL} / \mathrm{min}$; maker, Phenomenex; amino acid standard; and concentration, $200 \mu \mathrm{mol} / \mathrm{L}$.

\subsection{Fatty Acid}

Fatty acid of T65 crude product was determined by the GC-FID (gas chromatography-flame ionization detector) method at the Korea Polymer Testing and Research Institute (Koptri). For GC-FID, the machine used was Agilent 6890N GC-FID; column, Supelco SP-2500 (100 m ×0.25 mm $\times 0.20 \mu \mathrm{m})$; injection part temperature, $250{ }^{\circ} \mathrm{C}$; injection column, $1 \mu \mathrm{L}$; split ratio, 50:1; temperature condition, $100{ }^{\circ} \mathrm{C}(4 \mathrm{~min}) \rightarrow 3{ }^{\circ} \mathrm{C} / \mathrm{min} \rightarrow 240^{\circ} \mathrm{C}(15 \mathrm{~min})$; detector, FID @ $285^{\circ} \mathrm{C}$; carrier, nitrogen gas, $0.8 \mathrm{~mL} / \mathrm{min}$; maker, SUPELCO 37 Component FAME Mix; and concentration, $0.5 \mathrm{mg} / \mathrm{mL}$.

\subsection{Antimicrobial Activities}

Inhibition of pathogenic bacteria was performed by the disc diffusion method. One-hundred microliters of $P$. acnes culture at $10^{8} \mathrm{CFU}$ (colony-forming unit)/mL was spread and incubated at $35^{\circ} \mathrm{C}$ anaerobically for 2-3 days on Schaedler agar plates along with a $6 \mathrm{~mm}$ disc (Whatman) containing $15 \mu \mathrm{g}$ of crude extract dissolved in methanol, and the zones of inhibition were measured. Similarly, $100 \mu \mathrm{L}$ of S. epidermidis, S. aureus, B. subtilis, E. coli, and P. aeruginosa at $10^{8} \mathrm{CFU} / \mathrm{mL}$ were spread and incubated at $35^{\circ} \mathrm{C}$ aerobically on R2A or LBA plates for 1-2 days and the zones of inhibition were measured.

\subsection{Synthesis of Mesoporous Silica Particle}

The structure-inducing polymer was dissolved in deionized water to prepare a micelle solution. Mesoporous silica materials were synthesized according to the methods described in the literature [37]. For the synthesis of mesoporous silica particles (SBA-15), $10 \mathrm{~g}$ of Pluronic P123 $\left(\mathrm{EO}_{20} \mathrm{PO}_{70} \mathrm{EO}_{20}, \mathrm{BASF}\right.$ Corporation, Florham Park, NJ, USA), was dissolved in $55 \mathrm{~mL}$ of $2 \mathrm{M} \mathrm{HCl}$, followed by stirring at room temperature for $30 \mathrm{~min}$. Furthermore, $22 \mathrm{~g}$ of tetraethylorthosilicate (TEOS) was added to the solution and further stirred for $30 \mathrm{~min}$ and placed at $36^{\circ} \mathrm{C}$ for $24 \mathrm{~h}$ and then put into the oven, in which temperature was maintained at $100{ }^{\circ} \mathrm{C}$, and was left for 4 days under the static condition. After 4 days, the solution changed to a cloudy solution in the bottle. The cloudy solution was filtered with the two layers of cellulose filter paper and washed with EtOH (two times) and DI (deionized) water (two times). The resulting filtrated powder was dried in the $120^{\circ} \mathrm{C}$ convection oven and put into the muffle furnace (Hanyang Scientific Equipment Co., Ltd., Seoul, South Korea). Six samples were synthesized with the 
same conditions but in a different batch. Transmission electron micrographs (TEM) of synthesized SBA-15 were taken in Seoul National University by transmission electron microscopy (Talos L120C; FEI).

\subsection{BET Surface Area Analysis}

The particle size of silica was measured by the Mastersizer 2000 (Malvern Instruments Lt., Malvern, United Kingdom). For the sample preparation of BET (Brunauer-Emmett-Teller) analysis, $5 \mathrm{~g}$ of P-123 was added to $76 \mathrm{~g}$ of $2 \mathrm{M} \mathrm{HCl}$ and stirred at $250 \mathrm{rpm}$ for $24 \mathrm{~h}$. After $24 \mathrm{~h}$, when P-123 was completely dissolved, $160 \mathrm{~mL}$ of DI (deionized) water and TEOS were uniformly $(15 \mathrm{~mL} / \mathrm{min})$ added and stirred at $750 \mathrm{rpm}$ for $24 \mathrm{~h}$. After that, the formed powder was separated by filtering and the separated powder was placed into a thimble and washed with Soxhlet for $24 \mathrm{~h}$. Then, it was washed with DI water and burned in a muffle furnace (Hanyang Scientific Equipment Co., Ltd., South Korea). BET surface area analyses were conducted to confirm the performance of the powder produced by SBA-15 synthesis. BET analyses were completed by the Inha University and Changwon National University.

The gas sorption analyser (Autosorb iQ, Quantachrome Instruments, Ashland, OR, USA) was employed to examine the surface area and pore size distributions of prepared mesoporous silica materials. The surface area and pore size distributions were calculated using ASiQwin software (Anton Paar Quanta Tec Inc., Boynton Beach, FL, USA) based on adsorption-desorption isotherms. The pristine synthesized particles were degassed at $300^{\circ} \mathrm{C} / 3 \mathrm{~h}$, then $\mathrm{N}_{2}$ adsorption and desorption isotherms were measured at a temperature of $-196^{\circ} \mathrm{C}$. Multipoint BET analysis was applied for the total surface area calculation.

\subsection{Sustainability Assessment}

To confirm the presence of T65 in embedded SBA-15, the following performance was conducted as follows: $12 \mathrm{~g}$ of SBA-15 and $1.2 \mathrm{~g}$ of T65 crude product were mixed in $500 \mathrm{~mL}$ acetonitrile. The solution was stirred for $18 \mathrm{~h}$ under $30{ }^{\circ} \mathrm{C}$. After filtration, of the mixture was filtered and filtered particles were dried in a $100{ }^{\circ} \mathrm{C}$ convection oven. To find the T65 particle itself in SBA-15, $1 \mathrm{~g}$ of dried T65 embedded in SBA-15 was dissolved in acetonitrile and $25 \mathrm{~mL}$ of $3 \mathrm{M}$ fluoric acid was added. The mixture was stirred at room temperature for $24 \mathrm{~h}$ until the solution became clear. Then, the solution was filtered, and the filtrate solution was used as a sample. Samples obtained from the above experiments were analyzed by HPLC.

To determine the property of controlled release, $35 \mathrm{~mL}$ of embedded SBA-15 was poured into $50 \mathrm{~mL}$ of mineral oil (M3516; Sigma-Aldrich, St. Louis, MO, USA) and mixed well. Then, $50 \mathrm{~mL}$ of DI water was added to the mixture and shaken under room temperature for $6 \mathrm{~h}$, and then left on the desk for $12 \mathrm{~h}$. When the liquid layer was separated, the water layer was discarded, and $1 \mathrm{~mL}$ of oil layer was collected as a sample for HPLC analysis. The same experiment was repeated on the second and third day and the sample was again analyzed by using HPLC.

\subsection{Cosmetic Formulation and Application}

\subsubsection{Formulation and Stability Test}

A cosmetic product was formulated from an emulsifier-type cream. Cosmetic formulation stability was determined by keeping the cosmetic product at various temperatures $\left(37,45\right.$, and $\left.60{ }^{\circ} \mathrm{C}\right)$ including in the freezer, refrigerator, and at room temperature for up to 28 days. The stability of cosmetic cream was observed in the first, second, third, and fourth week.

\subsubsection{Clinical Trials, Volunteers, and Application Methods}

Functional cosmetic cream containing T65 crude product was applied to 21 female volunteers for determination of wrinkle improvement and whitening efficacy through skin roughness and skin brightness. All the experimental procedure for human involvement for this study were approved by the Ellead Institutional Review Board (IRB) (EL-P-7400). Informed consent was obtained from all 
individual participants. Tests were conducted before the application of the product, after 2 weeks and after 4 weeks. Approximately $5 \mathrm{mg}$ of cosmetic product was applied two times a day (morning and evening) on the face after cleansing the face, and it was softly spread according to the skin texture. The volunteers were not allowed to use any other creams or products 1 week prior to the trial and during the trial.

\subsubsection{Image Capturing and Processing Methods}

Pictures were captured by VISIA-CR. The roughness of images was analyzed by PRIMOS software (PRIMOS version 5.8E, Canfield Scientific, Inc., Parsippany-Troy Hills, NJ, USA). Average roughness (Ra) and maximum roughness depth (Rmax) were calculated using the following formula:

Ra or Rmax rate $(\%)=($ value before treatment - value after treatment $) /$ value before treatment $\times 100$

The brightness of images was analyzed by Chromameter CR-400. L* is the brightness parameter and is measured by the following formula:

$\mathrm{L}^{*}$ increasing rate $(\%)=($ value before treatment - value after treatment $) /$ value before treatment $\times 100$

\subsection{Statistical Analysis}

Statistical calculations of the $\mathrm{IC}_{50}$ value were performed by OriginPro 8.5 statistical software (OriginLab Corporation, Northampton, MA, USA). All experiments were conducted in triplicate, and all results were presented as mean \pm SD of three separate experiments. Data were analyzed by independent sample $t$-test one-way analysis of variance (one-way ANOVA), followed by Tukey's post-hoc test using OriginPro 8.5. Differences were considered significant at $p<0.05$.

\section{Results and Discussions}

\subsection{Isolation, Selection, and Phylogeny of Selected Active Strains}

A total of 2285 strains of bacteria were isolated from the collected soil samples. Screening results showed 102 strains of bacteria had functions applicable to the cosmeceuticals (Table S4). On the basis of primary screening, Streptomyces sp. T65 was found to have higher activities for all cosmetic applications, namely, anti-oxidant, anti-elastase, anti-tyrosinase, and antimicrobial activities. Finally, strain T65 was chosen for further assessment to identify its potential application in cosmeceuticals. Phylogenetic analysis showed that strain T65 formed a clade with Streptomyces bungoensis DSM $41781^{\mathrm{T}}$ (the closest strain on the basis of $16 \mathrm{~S}$ rRNA gene sequence) with a strong bootstrap value (Figure S1).

\subsection{Detection and Collection of Bioactive Material}

Mixed bioactive materials from T65 ethyl acetate culture extract was collected from Prep-HPLC. Bioactive materials were measured at 208, 230, 254, and $280 \mathrm{~nm}$ by detectors. The fractions were collected on the basis of time (from $14 \mathrm{~min}$ to $21 \mathrm{~min}$ ). The collected fractions were evaporated to dryness and dissolved in methanol (T65 crude product) and were used for all the assessments, including antimicrobial activities.

\subsection{Cytotoxicity in HaCaT Cell}

Cell viability in the human keratinocyte cell line (HaCaT cell) remained unaffected by $\mathrm{T} 65$ crude product up to $10 \mathrm{mg} / \mathrm{mL}$. On the other hand, cell viability increased in a dose-dependent manner when concentrations of $10 \mathrm{ng} / \mathrm{mL}$ to $10 \mathrm{mg} / \mathrm{mL}$ of the T65 crude product were applied (Figure S2). This concentration range resulted in more than $100 \%$ cell viability, indicating that it promoted the proliferation of $\mathrm{HaCaT}$ cells and was, thus, non-toxic to the HaCaT cell line. 


\subsection{Antioxidant Activities}

\subsubsection{Cytotoxicity in RAW264.7 Cell}

Cytotoxicity of the T65 crude product was assessed by cell viability in RAW264.7 macrophages by the MTT assay method. T65 crude product showed no cytotoxic effect on RAW264.7 cell lines (Figure 1).

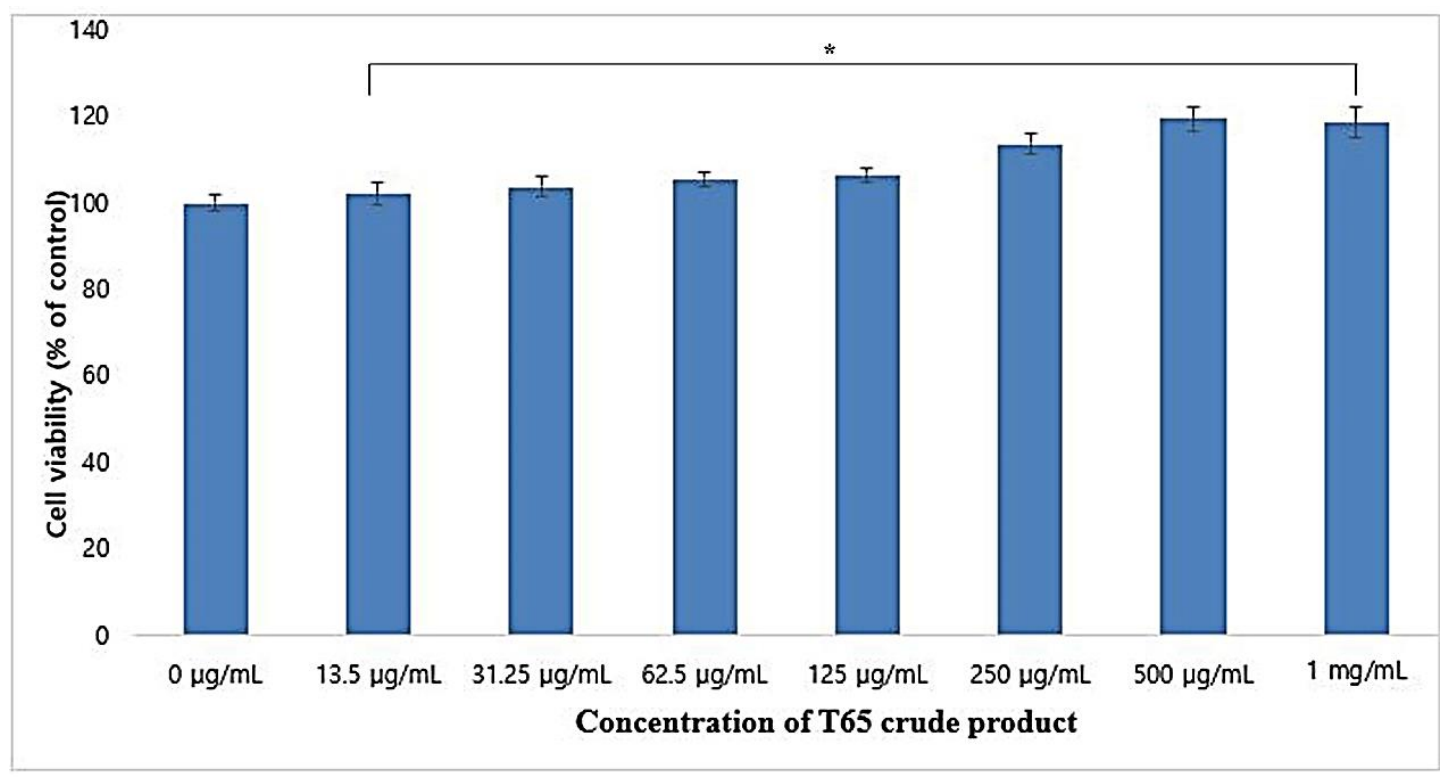

Figure 1. Assessment of cytotoxicity of T65 crude product in RAW264.7 cells. Values are given as mean \pm SEM (standard error of the mean). ${ }^{*} p<0.05$ compared to control.

On the contrary, T65 crude product helped to proliferate RAW264.7 cells in a dose-dependent manner when treated with 13.5 to $1000 \mu \mathrm{g} / \mathrm{mL}$. When $1000 \mu \mathrm{g} / \mathrm{mL}$ T65 crude product was used, the cell viability of RAW264.7 cells were $118.7 \%(p<0.05)$. These results showed that the T65 crude compound was non-toxic up to $1 \mathrm{mg} / \mathrm{mL}$ and could be used in cosmeceutical formulations.

\subsubsection{Inhibition of Nitric Oxide (NO) Production}

Griess reagent was used to determine the NO levels. To determine the NO inhibition, RAW264.7 cells were treated with $1 \mu \mathrm{g} / \mathrm{mL}$ LPS (lipopolysaccharide) along with various concentrations of T65 crude product. RAW264.7 cells were activated by LPS, and NO production was measured as nitrite concentration in the culture medium. Compared to LPS alone, T65 crude product significantly $(p<0.001)$ inhibited the nitrite concentration in the LPS-stimulated RAW264.7 cells in a concentration-dependent manner when used from 15.5 to $125 \mu \mathrm{g} / \mathrm{mL}$ (Figure 2). The macrophages were LPS-Toll-like expression of inducible NO synthase (iNOs) by signaling cell activation via receptors [38]. LPS is an activator of macrophages and plays an important role in the production of NO in mammalian cells [39]. NO is a free radical produced by immunocompetent cells such as macrophages [40]. Production of NO has a phagocytic effect on macrophages. Thus, macrophage cell line RAW264.7 was selected for antioxidant assay. For a long time, considerable attention has been given to the quest of natural antioxidants to inhibit NO production [41]. At $125 \mu \mathrm{g} / \mathrm{mL}, \mathrm{T} 65$ crude product sufficiently decreased the NO levels by $57.4 \%$ compared to the NO produced by $1 \mu \mathrm{g} / \mathrm{mL}$ LPS. On the basis of inhibition of NO produced in LPS-induced RAW264.7 macrophage cell line, the T65 culture extract could be considered a potent antioxidant. 


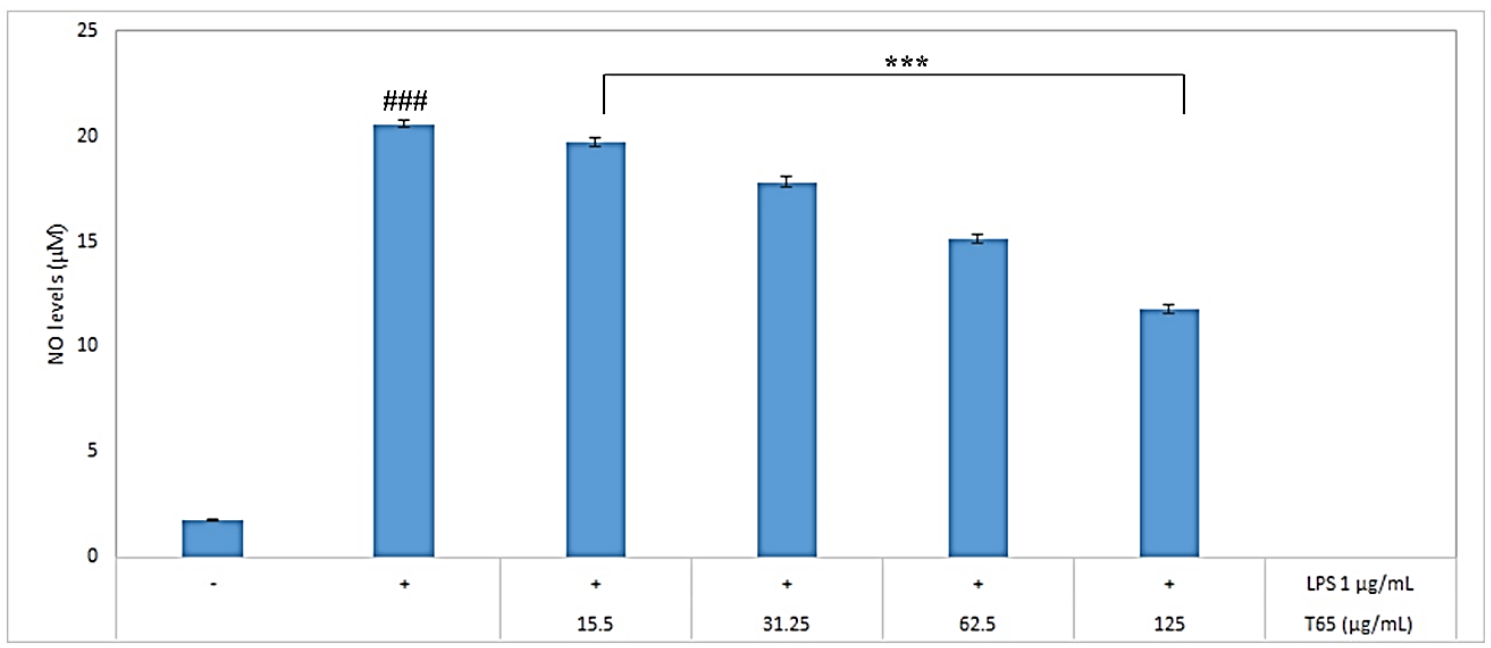

Figure 2. Evaluation of NO inhibition by T65 crude product. Values are given as mean \pm SEM. \#\#\# $p<0.001$ compared to untreated control and ${ }^{* * *} p<0.001$ compared to lipopolysaccharide (LPS) alone.

\subsubsection{DPPH Radical Scavenging Activity}

$\mathrm{DPPH}$ radical scavenging percentages at different concentrations and $\mathrm{IC}_{50}$ value of $\mathrm{T} 65$ crude product are given in Table S5. Ascorbic acid (vitamin C) was used as a standard because it is used in lotions, creams, serums, and patches, which are well known to have powerful antioxidant activities for topical applications [42]. $\mathrm{IC}_{50}$ for DPPH radical scavenging activities for vitamin $\mathrm{C}$ and $\mathrm{T} 65$ secondary product were found to be 5.01 and $6.31 \mu \mathrm{g} / \mathrm{mL}$, respectively (Figure 3).

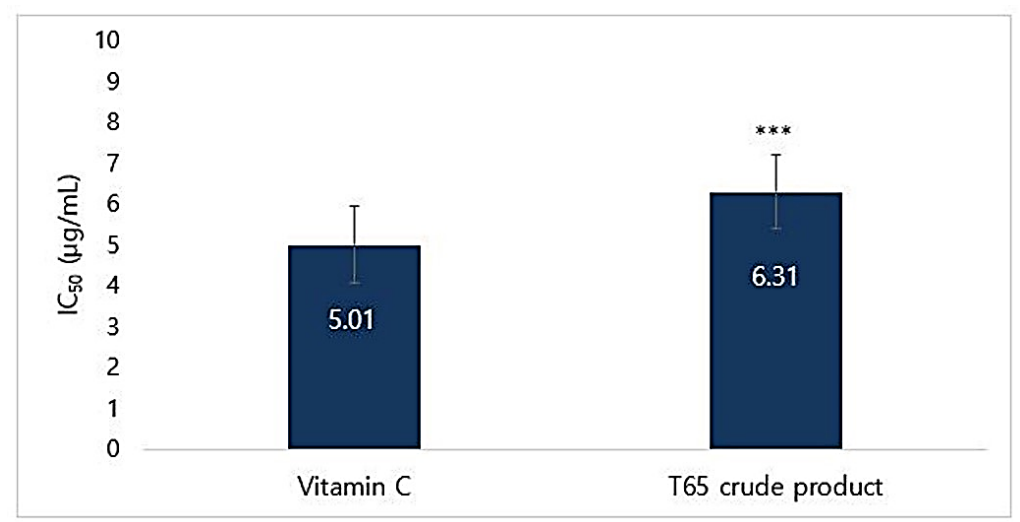

Figure 3. $\mathrm{IC}_{50}$ of 1,1-diphenyl-2-picrylhydrazyl (DPPH) radical scavenging activities of T65 crude product and vitamin C. Data are given as mean \pm SEM. Statistical significance is shown by ANOVA $(* * * p<0.001)$.

There are only a few studies about the antioxidant activities from bacterial isolates compared to those from plant materials and most studies have focused on well-established plant products [43-49]. A concentration of $10 \mu \mathrm{g} / \mathrm{mL}$ product was able to scavenge $68.66 \pm 2.83 \%$ of $\mathrm{DPPH}$-free radical. The $\mathrm{IC}_{50}$ of T65 crude product was almost comparable to that of the strongest antioxidant vitamin C, which showed that it could be used as an antioxidant agent in the formulation of cosmeceuticals.

\subsection{Antiaging Activities}

\subsubsection{Cytotoxicity in CCD-986Sk Cells}

Cytotoxicity of crude compounds of T65 in human dermal fibroblast (HDF) cells was evaluated in the CCD-986Sk cell line using the MTT assay. When the concentration of T65 crude product from 0 to 
$1 \mathrm{mg} / \mathrm{mL}$ were supplied, the HDF cells proliferated in a dose-dependent manner until the concentration of $500 \mu \mathrm{g} / \mathrm{mL}$. This result showed that the crude compounds from T65 were non-cytotoxic to HDF cells. However, a concentration of more than $1 \mathrm{mg} / \mathrm{mL}$ was found to be cytotoxic, and only $81.34 \%$ of the cells survived compared to the control (Figure 4).

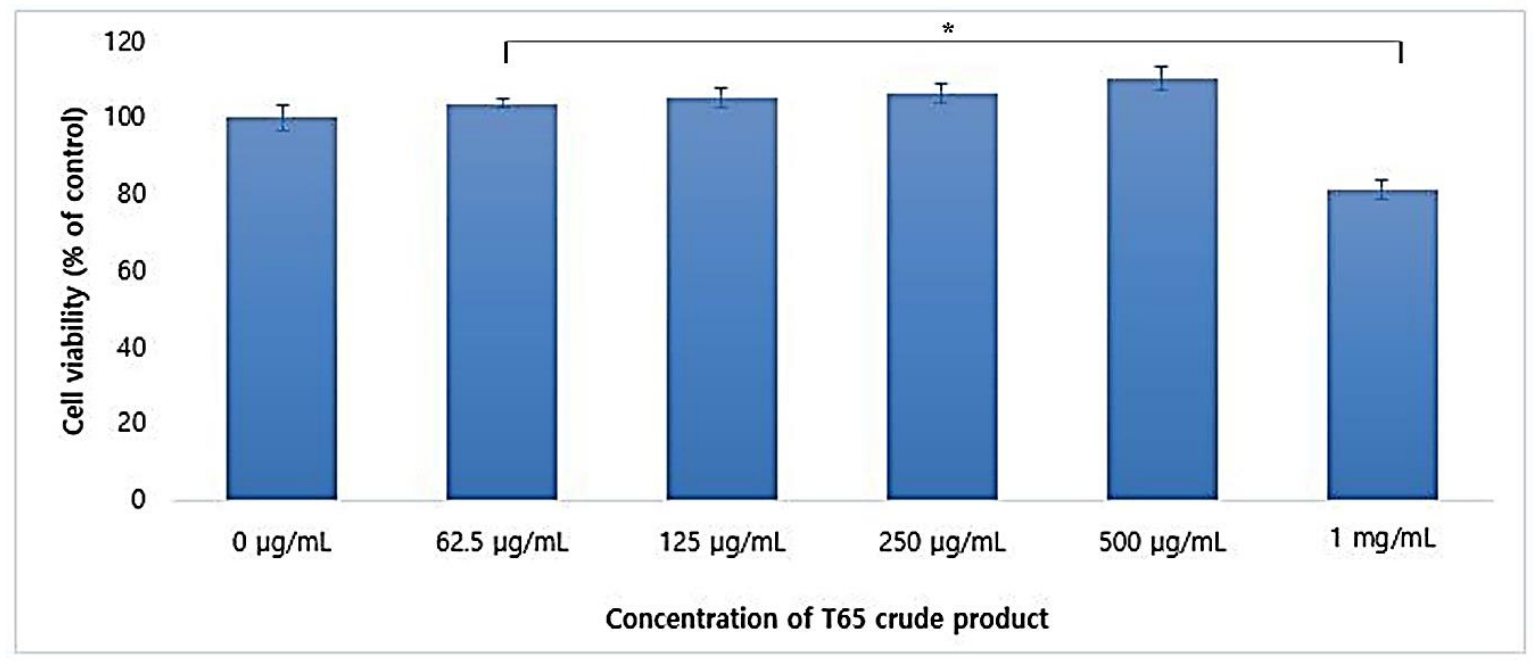

Figure 4. Cell viability assessment of T65 crude product in human dermal fibroblast (HDF) cells using CCD-986Sk cell line. Data are given as mean \pm SEM. ${ }^{*} p<0.05$ compared to control.

\subsubsection{Proliferation of HDF}

The proliferation of HDF cells was determined using the CCD-986Sk cell line. T65 crude product proliferated the HDF cells in a concentration-dependent manner from 0 to $500 \mu \mathrm{g} / \mathrm{mL}$ (Figure 5). However, it was cytotoxic at a concentration of $1 \mathrm{mg} / \mathrm{mL}$. Human dermal epithelial cell growth confirmed wrinkle improvement ability through the change in the primary cultured cells isolated from human dermal cells and secreted collagen [50,51].

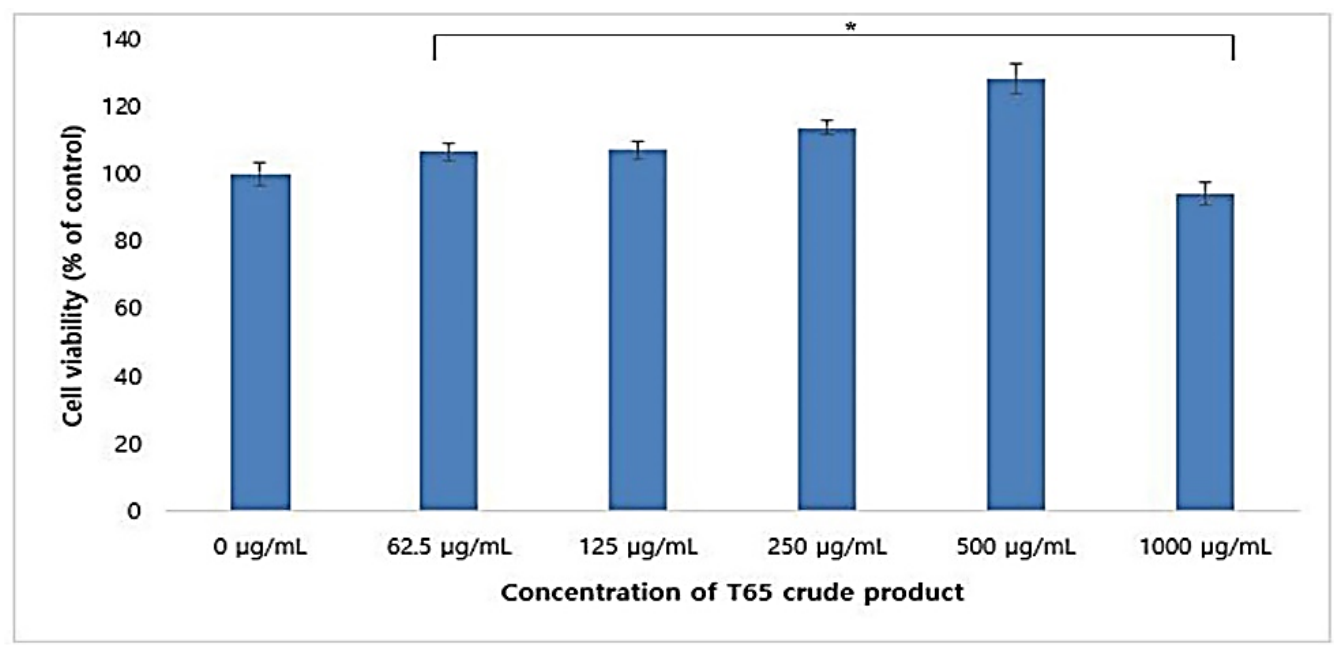

Figure 5. Proliferation of human dermal fibroblast (HDF) cells evaluated in CCD-986Sk cell line. Data are given as mean \pm SEM. ${ }^{*} p<0.05$ compared to control.

\subsubsection{Collagen Type I Synthesis}

Synthesis of collagen type I was detected by ELISA. The crude product of T65 at $250 \mathrm{pg} / \mathrm{mL}$ increased the concentration of collagen type I in a dose-dependent manner up to $145.91 \% \pm 9.11 \%$ (mean \pm SD; mean of 24,48 , and $72 \mathrm{~h}$ ). The result of three experiments at 24,48 , and $72 \mathrm{~h}$ showed the 
synthesis of type I collagen (Figure 6). Thus, dermal cell secretion of collagen accompanied by human dermal epithelial cell growth confirmed the wrinkle-improvement ability of T65 compounds.

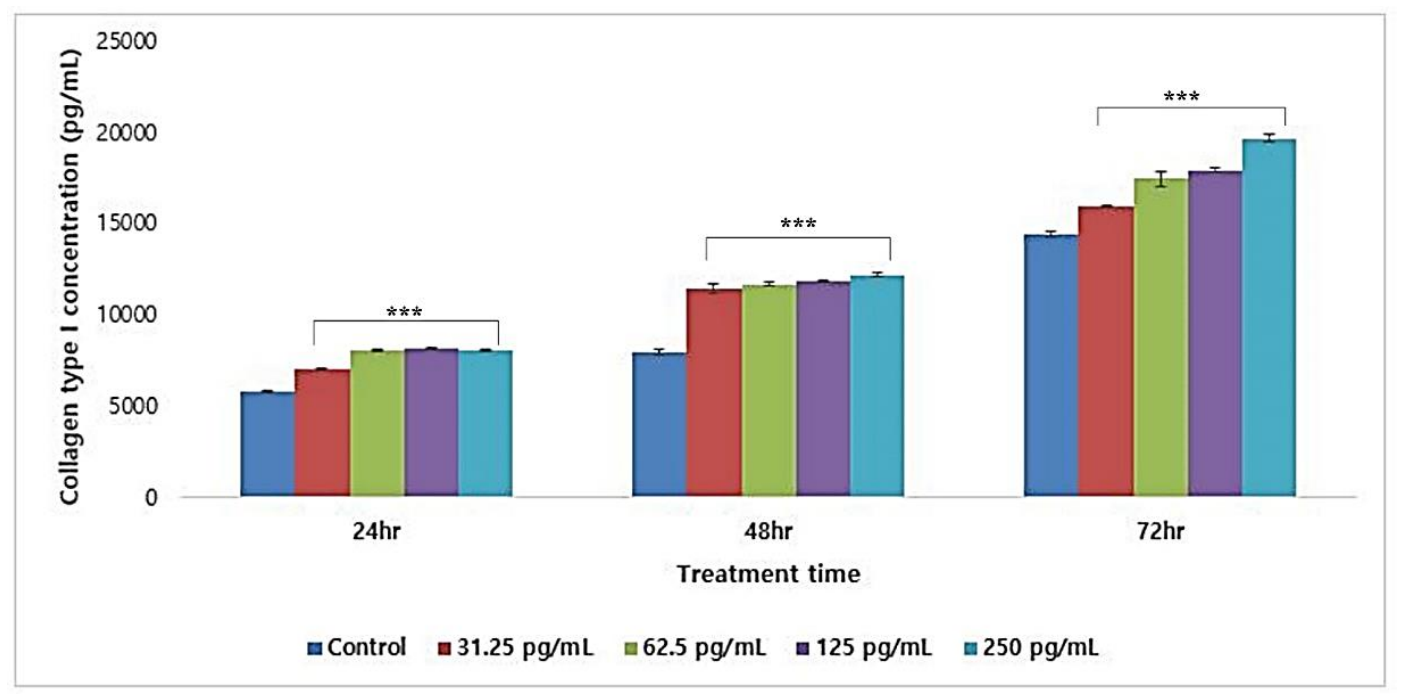

Figure 6. Synthesis of collagen type I using T65 crude product in 24,48 , and $72 \mathrm{~h}$. Data are given as mean \pm SEM. ${ }^{* * *} p<0.05$ compared to control in respective hours.

\subsubsection{Elastase Inhibition Assay}

The T65 crude product showed strong porcine pancreatic elastase inhibition activity. The $\mathrm{IC}_{50}$ values of T65 and oleanolic acid (commercialized inhibitor used in cosmeceuticals) were 10.19 and $14.68 \mu \mathrm{g} / \mathrm{mL}$, respectively (Figure 7). T65 showed a slightly lower inhibitory activity in comparison to the positive standard. However, T65 crude product inhibited $84.98 \%$ of elastase at a concentration of $300 \mu \mathrm{g} / \mathrm{mL}$ (Table S6). These results showed that the compounds of T65 from the ethyl acetate extract had a strong potential to be used in cosmetic formulations.

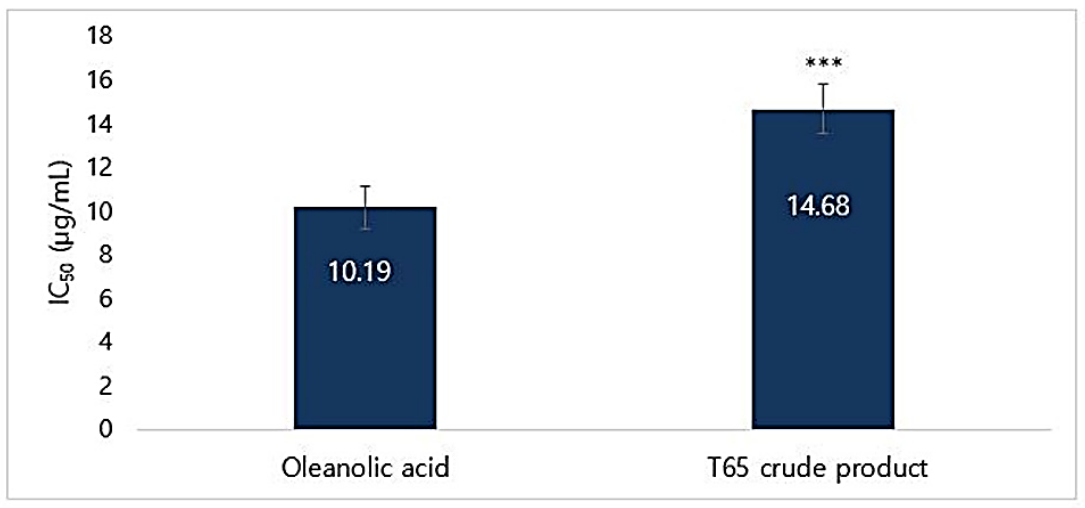

Figure 7. $\mathrm{IC}_{50}$ of porcine pancreatic elastase (PPE) inhibition using T65 crude product and oleanolic acid. Data are given as mean \pm SEM. Statistical significance is shown by ANOVA $(* * *<0.001)$.

\subsection{Whitening Activities}

\subsubsection{Cytotoxicity in B16F1 Cells}

The result of cytotoxicity of T65 crude product on B16F1 melanoma cells by the MTT assay is shown in Figure 8. The outcome of incubation of T65 crude product in B16F1 cells showed non-toxic effects up to $1 \mathrm{mg} / \mathrm{mL}$ concentration. B16F1 cells proliferated in a dose-dependent manner up to a concentration of $62.5 \mu \mathrm{g} / \mathrm{mL}$, but a significant $(p<0.05)$ dose-dependent decrease in cell viability was evaluated from 125 to $1000 \mu \mathrm{g} / \mathrm{mL}$. However, at a concentration of $1 \mathrm{mg} / \mathrm{mL}, 99.12 \% \pm 4.16 \%$ of viable 
cells were observed (Figure 8). The experimental results showed that the ethyl acetate extract of strain T65 culture was non-cytotoxic to the B16F1 melanoma cell line and could be used in the formulation of cosmetic products for whitening of human skin.

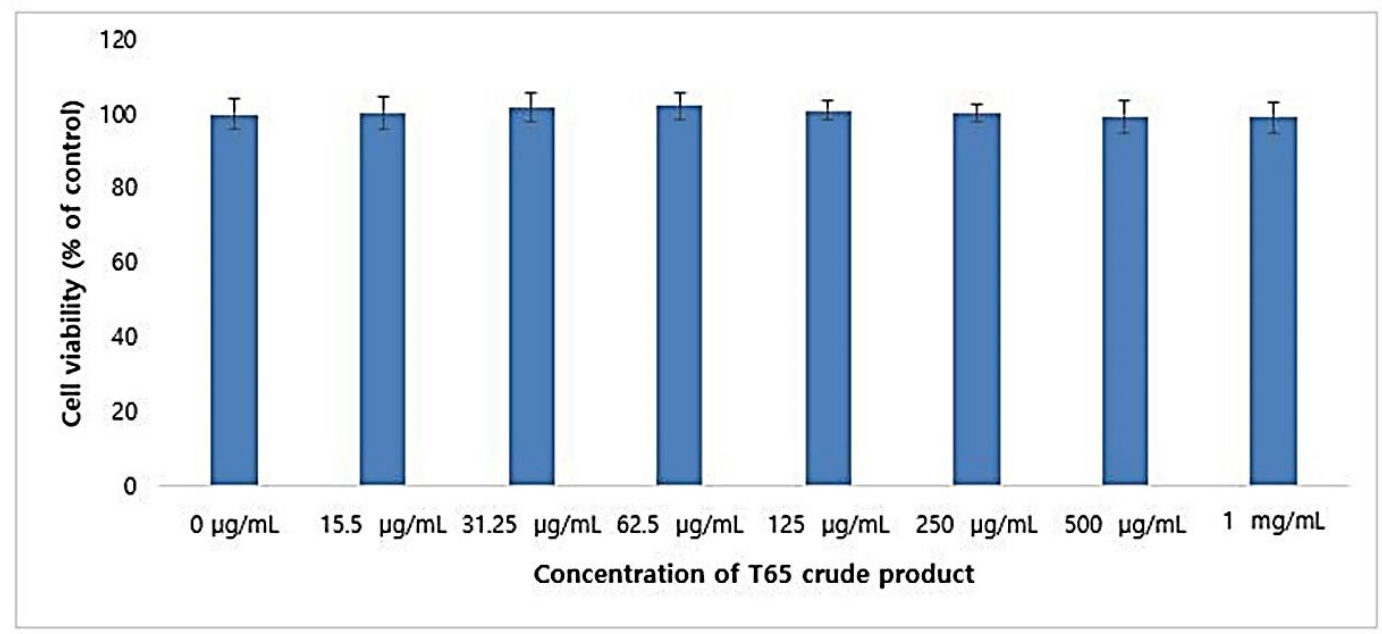

Figure 8. Cytotoxicity of T65 crude product in B16F1 melanoma cells. Data are given as mean \pm SEM.

\subsubsection{Melanin Synthesis Inhibition in B16F10 Cells}

For confirmation of the whitening effect, B16F10 cells, a cell line that secretes and produces melanin in cells, were used. To promote melanin synthesis, B16F10 was supplemented with $1 \mu \mathrm{g}$ of $\alpha$-MSH. Arbutin (100 $\mu \mathrm{g} / \mathrm{mL}$; a commercialized whitening agent) was used as the positive control. The microscopic observation of this experiment showed almost complete inhibition of melanin by application of $125 \mu \mathrm{g} / \mathrm{mL}$ of T65 culture extract in $48 \mathrm{~h}$ (Figure 9A, B). This experiment proved that T65 culture extract has the potential to inhibit melanin synthesis in a dose-dependent manner and can be used as a whitening agent for the formulation of cosmetic products for topical applications.

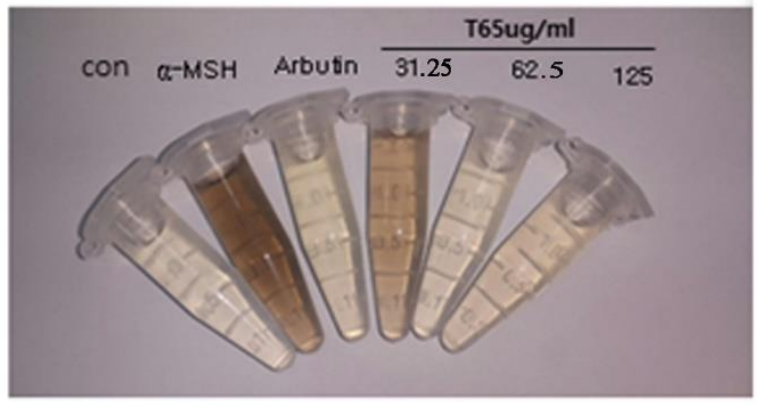

A

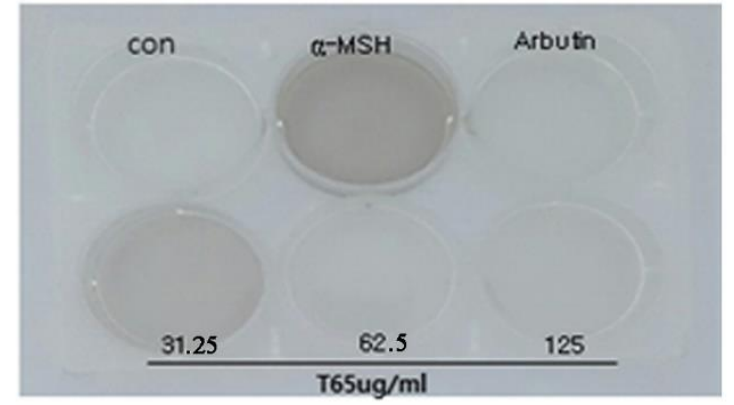

B

Figure 9. Confirmation of whitening effect in B16F10 cells by T65 crude product. $\alpha$-MSH: $\alpha$-melanocyte stimulating hormone used to stimulate melanin. (A) Experiment performed in Eppendorf's tube; (B) experiment performed in 6-well plate.

\subsubsection{Mushroom Tyrosinase Inhibition Assay}

The T65 crude product was tested for inhibitory effects on mushroom tyrosinase by using L-tyrosine as a substrate. Percentages of inhibition of mushroom tyrosinase were measured. Arbutin was used as the positive control. Calculated $\mathrm{IC}_{50}$ values for $\mathrm{T} 65$ crude product and arbutin were found to be 58.73 and $50.48 \mu \mathrm{g} / \mathrm{mL}$, respectively (Figure 10). At a concentration of $300 \mu \mathrm{g} / \mathrm{mL}$, T65 inhibited $84.98 \%$ of mushroom tyrosinase (Table S7). $\mathrm{IC}_{50}$ of the T65 culture extract was slightly lower than that of arbutin. However, the mushroom tyrosinase inhibition and melanin synthesis inhibition activities suggested 
that the culture extract of T65 was a non-cytotoxic strong whitening agent that could be used in the formulation of cosmeceuticals.

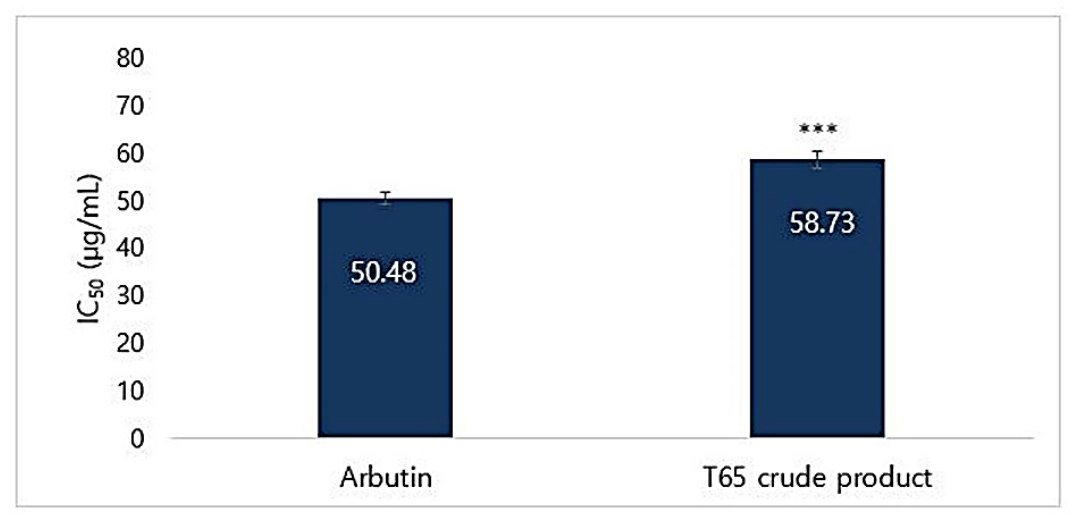

Figure 10. $\mathrm{IC}_{50}$ of mushroom tyrosinase inhibition by $\mathrm{T} 65$ crude product and arbutin. Data are given as mean \pm SEM and statistical significance is shown by ANOVA $(* * *<0.001)$.

\subsection{Analysis of Amino Acids}

Analyses of free amino acids from T65 crude product were conducted by the Korea Polymer Testing and Research Institute (Seoul, South Korea). The total concentration of free amino acids obtained was $2328 \mathrm{mg} / \mathrm{kg}$ (Table S8). The amino acid with the highest concentration was valine (21.43\%) and that with the least concentration was $\alpha$-aminobutyric acid $(0.81 \%)$. Characteristic composite amino acids are shown in Table S9. Eight different types of amino acids were determined as composite amino acids and the concentration of leucine was the highest (20.36\%), whereas that of alanine was the lowest. Amino acids are protein substrates and are highly safe for humans, being commonly used in cosmetic ingredients [52,53]. Studies have shown that amino acids and their derivatives are an effective measure to suppress the signs of aging, oxidative stress, and melanogenesis [52,54-57].

Branched chain amino acids (BCAAs) (isoleucine, leucine, and valine) not only inhibit the melanogenesis but also restore the dermal collagen [52,58]. Specific amino acids, such as glycine and proline, are necessary to stimulate dermal tropocollagen synthesis [52]. In addition, free amino acids, such as alanine, proline, serine, glycine, methionine, tryptophan, lysine, and valine, lower the inflammation and oxidative stress by decreasing ROS production [56]. Aspartic acid and glutamic acid also possess antioxidant activities [59]. Furthermore, one or more residues of glutamic acid, lysine, aspartic acid, valine, alanine, proline, methionine, tryptophan, and phenylalanine improve the antioxidant activity $[55,60]$. Valine, leucine, serine, alanine, glycine, and glutamic acid have been reported to contribute to metal-chelating activity and tyrosinase-inhibition [57,61]. In T65 crude product, various residues of free and composite amino acids were detected that were capable for antioxidant, anti-aging, and anti-tyrosinase activities. Thus, bioactive material in T65 crude product may be composed of various peptides of more complete amino acids, reflecting its multi-functional activities. However, these mechanisms are complex and need further investigation.

\subsection{Fatty Acids}

Out of 37 types of fatty acids, only five (butyric acid, lauric acid, stearic acid, oleic acid, and palmitic acid) were detected by GC-FID. The highest concentration was of butyric acid $(544 \mathrm{mg} / \mathrm{kg}$; $54.67 \%$ ). Fatty acid compositions of the extract are shown in Table S10. All the detected fatty acids in T65 crude product have been reported to have antioxidant activity [62-66].

\subsection{Antimicrobial Activities}

Five different types of solvent were used to extract the concentrated culture supernatant of strain T65. The inhibition zone (mean $\pm \mathrm{SD}$ ) using $15 \mu \mathrm{g}$ of each extract are shown in Table S11. Among the 
five extracts, ethyl acetate extract had a higher inhibition for pathogenic bacteria. Inhibitory activity of ethyl acetate extract of strain T65 was greater than that of other solvent systems inhibiting the pathogens, including P. acnes, S. aureus, and S. epidermidis (Table S11). In addition, crude product from T65 inhibited P. acnes, S. aureus, S. epidermidis, B. subtilis, and E. coli (Figure S3; Table S12). These results suggest that strain T65 had a broad range of antimicrobial action and is able to inhibit Gram-positive as well as Gram-negative pathogens. Particularly, colonization of pathogenic bacteria, such as P. acnes and S. epidermidis, cause acne vulgaris (common skin disorder or a kind of infection of human skin that affects up to $80 \%$ of people), and S. aureus causes nosocomial infection in the human face and skin $[67,68]$. Thus, the inhibition of these pathogens may help to reduce the colonization of such pathogens and to keep the skin healthy. In addition, inhibition of pathogens, such as B. subtilis, E. coli, and $P$. aeruginosa, may prevent the cosmetic emulsions from spoiling.

\subsection{Mesoporous Silica Materials}

Mesoporous material is a material containing pores with a diameter of 2 to $50 \mathrm{~nm}$ according to IUPAC (International Union of Pure and Applied Chemistry) nomenclature, and thus mesoporous silica material is a silica material that has pores that are $2-50 \mathrm{~nm}$ in diameter. This material was reported in the 1970s firstly in U.S. patents, but was not well noticed to the related fields, and thus similar material was independently researched and synthesized by Japan again in 1990 [69]. More detailed research was followed by Mobil Corporation Laboratories, and they named this material MCM (Mobil crystalline material), with examples such as MCM-41 or MCM-48, of which the mesopore diameter ranges from 2 to $6 \mathrm{~nm}[70,71]$. Another research group in the University of California, Santa Barbara, succeeded in synthesizing a larger pore size $(5-30 \mathrm{~nm})$ mesoporous silica 6 years later, and they named it SBA (Santa Barbara amorphous material)-15 [72]. Mesopore silica material was designed at first to use as a molecular sieve due to its own structural character, but recently it has found a wide range of applications in drug delivery, catalyst, biosensor, energy storage, and so forth.

There are various differences in SBA- 15 and MCM- 41 mesoporous materials. However, the simplest way to distinguish these two is the silica wall thicknesses. The SBA-15 with a thicker silica wall has a more stable and rigid structure compared to that of MCM-41, which has thinner wall thickness. Moreover, the synthetic method of SBA-15 is simpler than that of MCM-41. Due to these differences, SBA-15 was selected to carry bioactive T65 crude product inside the mesopore of the silica material.

\subsection{Synthesis of Mesoporous Silica Particles}

After the calcination process was carried out under $200^{\circ} \mathrm{C}$ for $2 \mathrm{~h}$ and $600^{\circ} \mathrm{C}$ for $3 \mathrm{~h}$ continually, the resulting white silica mesoporous powder was obtained. SBA- 15 of $8 \mathrm{~nm}$ pore were synthesized in this process. The particle sizes of SBA-15 were found to be $11.539-13.630 \mathrm{~mm}$ in diameter (Figure S4) and were determined by two different facilities: the Inha University Laboratory and the Changwon National University Laboratory. In addition, all the six samples in Figure S4 were synthesized by the same method but a different batch.

When the mixture was maintained at $60^{\circ} \mathrm{C}$ and left for 4 days under static condition following the above method, SBA- 15 of $5 \mathrm{~nm}$ pore was acquainted. Additionally, when the temperature was controlled at $120^{\circ} \mathrm{C}, \mathrm{SBA}-15$ of $10 \mathrm{~nm}$ was synthesized. According to the results, mesopore size can be controlled depending on the aging process [73]. SBA-15 of $10 \mathrm{~nm}$ pore (Figure 11) was used for further processing because large pore mesoporous silica nanomaterials have better delivery actions for biomolecules than the narrow pore [74]. 

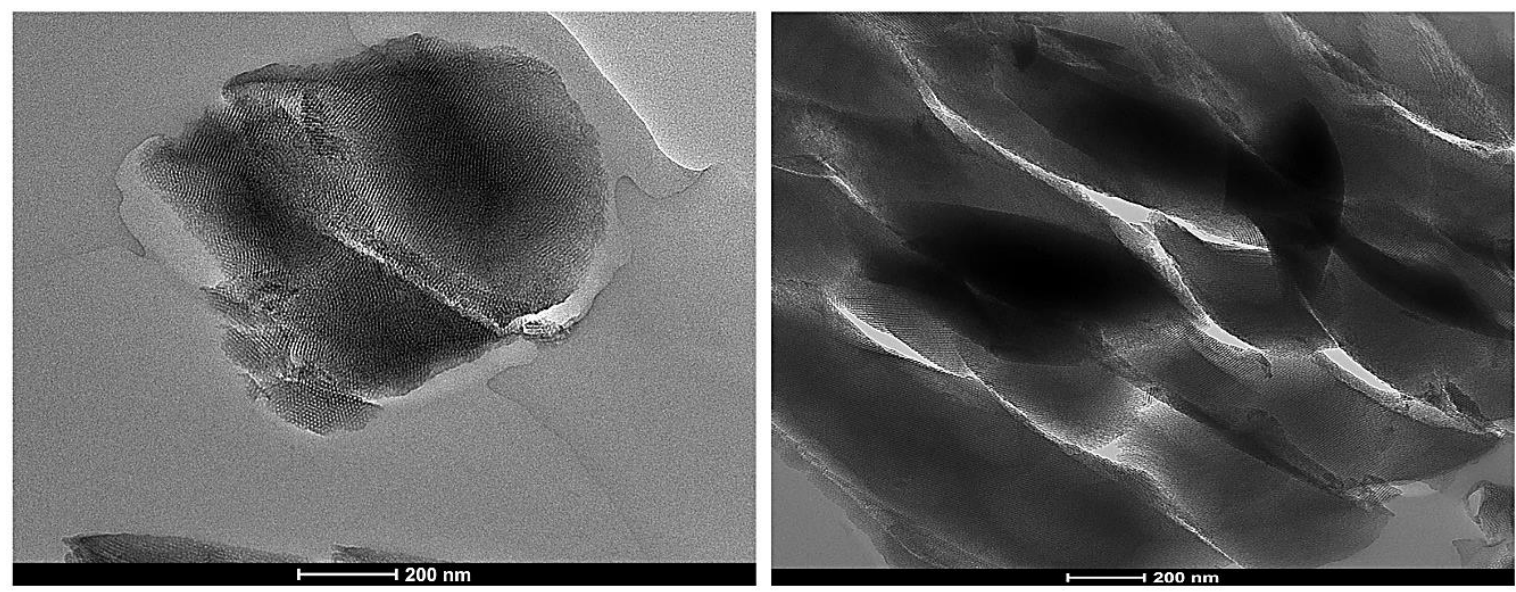

Figure 11. TEM (transmission electron microscopy) photomicrograph of synthesized mesoporous silica particles (SBA-15). Bar, $200 \mathrm{~nm}$.

\subsection{BET Surface Analyses}

The pore volume (PV) value of synthesized mesoporous SBA-15 ranged from $35 \%$ to $49 \%$ (average $42 \%$ ) depending on the synthetic conditions (Table 1). In addition, models of DFT (density functional theory) were used to determine the pore size distribution, and were also compared to relatively old BJH (Barret-Joyner-Halenda) [75].

Table 1. Brunauer-Emmett-Teller (BET) analysis of SBA-15.

\begin{tabular}{ccccc}
\hline SN & Sample & BSA & PV & PS \\
\hline 1 & SB0053-18 & 708.8383 & 0.382060 & 21.5598 \\
2 & SB0053-35 & 278.9649 & 0.367949 & 52.7593 \\
3 & SB0053-36 & 345.9479 & 0.485290 & 56.1114 \\
4 & SB0053-60 & 284.7321 & 0.372607 & 52.3449 \\
5 & SB0053-3 & 348.2327 & 0.489289 & 56.2025 \\
6 & SB0053-2 & 559.3040 & 0.423800 & 30.3096 \\
\hline
\end{tabular}

SN: serial number; BSA: BET surface area $\left(\mathrm{m}^{2} / \mathrm{g}\right)$; PV: pore volume $\left(\mathrm{cm}^{3} / \mathrm{g}\right)$; PS: pore size $(\AA)$.

In the environmental science field, pore volume (PV) is used to determine space volume in the particles. To determine the volume ratio more easily, the percentage unit is used rather than the decimal unit. For example, PV is written as 0.372607 (the unit is $\mathrm{cm}^{3} / \mathrm{g}$ ); it can also be described as $37.3 \%$. Compared to the normal spherical silica $\left(\mathrm{SiO}_{2}, \mathrm{PV} \approx 0.2\right.$ on average) or spherical titania $\left(\mathrm{TiO}_{2}\right.$, $\mathrm{PV}<0.1$ ), synthesized mesoporous SBA-15 shows a very efficient volume/mass ratio. Additionally, in this study, we achieved a porosity of $30 \%$, which was established as a quantitative target.

\subsection{Sustainable Performance Evaluation}

To determine whether the mesoporous SBA-15 has a controlled-release ability, SBA-15 and the T65 crude product were combined together in DI water, methanol, acetonitrile, or ethylene glycol solvent. When SBA-15 and water were mixed, the solution became a slurry because of the coagulation between the silica surface and water. Methanol was a good solvent for both silica and T65 crude product. However, because of toxicity, methanol was substituted for acetonitrile. The particles for the T65 immersion ratio were determined by the PV value (Table S13). As shown in Table S13, the PV value of SBA-15 decreased after immersion with the T65 crude product. This showed that the T65 materials were immersed well inside the mesoporous silica particles.

To determine whether there was T65 inside the particle, T65 itself was investigated by HPLC (Figure S5). As shown by the data, there were two specific peaks (inside the red box) that were 
always visible in the case of the T65 culture extracts, even though the T65 preparation batch was changed. These two peaks had retention times of $10 \mathrm{~min}$ and $12 \mathrm{~min}$ at $230 \mathrm{~nm}$. The filtrate sample was investigated in HPLC to determine whether T65 was present inside the embedded SBA-15. As shown in Figure S6, two specific peaks were observed near $10 \mathrm{~min}$ and $12 \mathrm{~min}$. Furthermore, a small peak was observed near 18 min of retention time, which is very important to trace the T65 products that are time-released.

Figure 12 represents the controlled release of the sustainable test of T65 embedded SBA- 15 from 0 to 3 days. The specific peak of T65 was visible near 15 and $20 \mathrm{~min}$ from days 0 to 3 . The T65 crude products were properly immersed and were gradually secreted over time. In addition, the silica mesoporous materials (SBA-15) proposed in this study could carry physiologically active substances in the T65 crude product and confirmed that the physiologically active substances were released in a sustained release manner after loading. Moreover, the silica mesoporous material proposed in this study could, in the future, be used as a good carrier to impregnate various functional materials and as a sustained-release material by supporting various physiologically active substances.

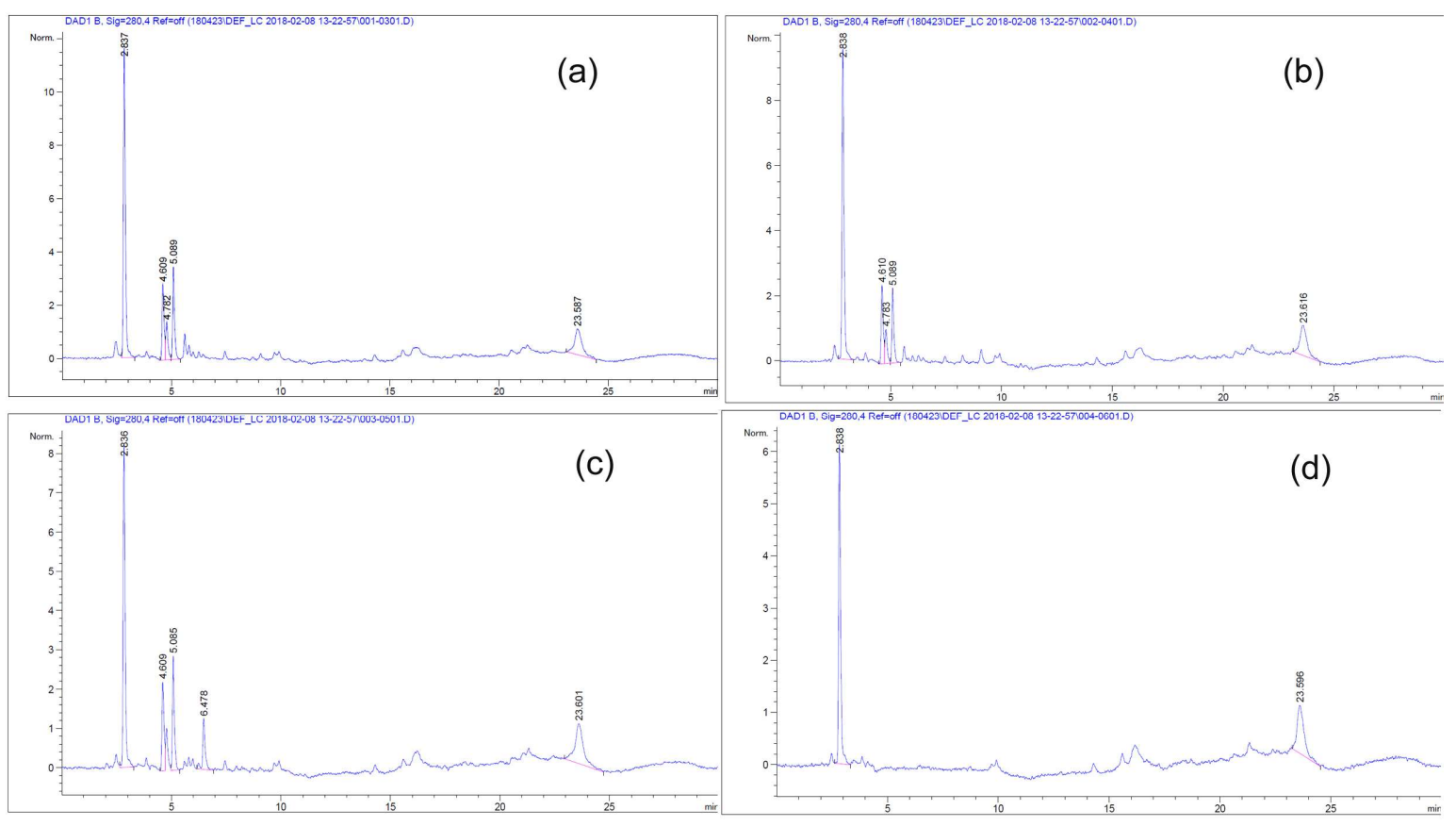

Figure 12. HPLC chromatogram of T65 embedded SBA-15 for sustainable control release test. (a) 0 day, (b) first day, (c) second day, and (d) third day.

\subsection{Cosmetic Formulation and Topical Application}

The final cosmetic product (Figure S7) was formulated with various ingredients, as shown in Figure S8. The formulated cosmetic emulsion was between an essence and cream, having a certain amount of moisture with a low degree of oiliness. It had a feeling of oiliness just before the skin application. The final product of formulated cosmetic cream was designed on the basis of feeling and emulsifier-type cream. The formulation did not have a high degree of oiliness. After a certain period of time, the absorbency of the skin increased, leaving a moist feeling.

\subsubsection{Formulation Stability}

The cosmetic samples were stored in the freezer, refrigerator, and at room temperature $(37,45$, and $60^{\circ} \mathrm{C}$, respectively) for weeks. After 4 weeks, observations confirmed no separation or loose texture, and the stability of the cream was maintained. However, at $60^{\circ} \mathrm{C}$ after the third and fourth week the formulated cream was observed to become slightly loose (Table S14). 


\subsubsection{Clinical Trails}

Formulated cosmetic cream was applied to 21 female volunteers. The age of volunteers was between 38 and 60 years (mean age \pm SD, $46.43 \pm 5.01$ ). Determination of wrinkle improvement and whitening evaluation were conducted on the basis of skin roughness and skin brightness.

\subsubsection{Image Capturing and Processing}

Face pictures of volunteers were captured by VISIA-CR. The roughness of captured images was analyzed using PRIMOS software (PRIMOS version 5.8E, Canfield Scientific, Inc., Parsippany-Troy Hills, NJ, USA) and brightness of images was analyzed using Chromameter CR-400. The three-dimensional measurement of PRIMOS was based on the computer-assisted calculation of the parallel stripes projected onto the skin according to the height difference of the skin surface. Using the 3D matching method, the corrugation images measured by PRIMOS were matched with the measured areas and the parameters through roughness analysis. Average roughness depth (Rmax) of the absolute values was the length from the centerline to the cross-section of the surface when drawing the centerline at the roughness height of the cross section. The results of analysis of the values of the eye wrinkle roughness using PRIMOS High Resolution showed that the Ra value was statistically significant $(p<0.001)$ compared to that after sample application and decreased by $4.656 \%$ after 4 weeks of application (Figure 13).

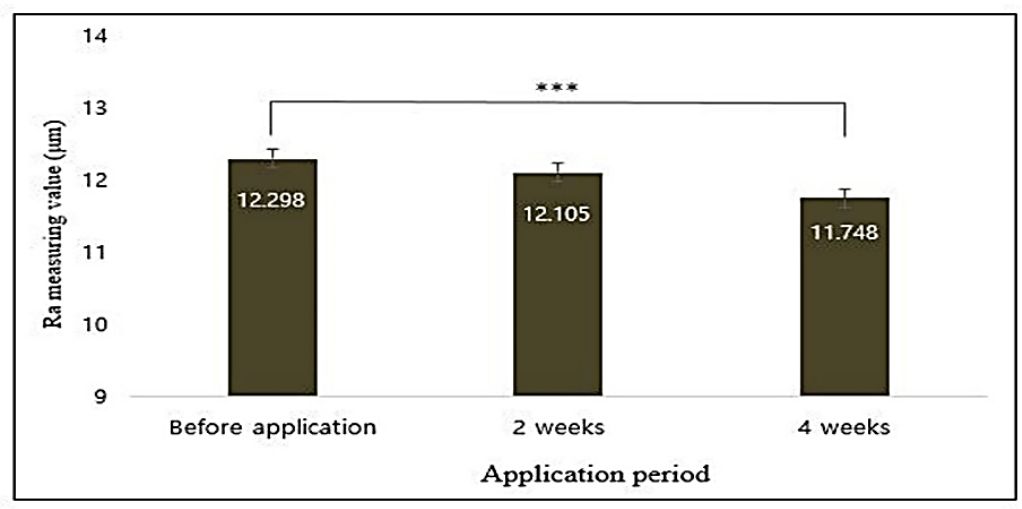

Figure 13. Correlation between application period of formulated cosmetics product and eye wrinkle average roughness values ( $\mathrm{Ra}$ ) analyzed using PRIMOS High Resolution. Data are given as mean \pm SEM and statistical significance is shown by ANOVA $(* * * p<0.001)$.

Rmax values were statistically significant $(p<0.05)$ as compared to those before application of the sample and decreased by $2.198 \%$ and $4.670 \%$ after 2 and 4 weeks of application, respectively (Figure 14). Therefore, it was considered that the T65 crude product complex functional cream helped to reduce the roughness of the eye folds after 2 and 4 weeks of application.

The $L^{*}$ value of the ball area using the chromameter was statistically significant $(p<0.001)$ compared with that before the application of the sample, and increased by $0.472 \%$ after 4 weeks of application (Figure 15). This result confirmed that the T65 crude product complex functional cream helped to improve skin brightness after 4 weeks of application. 


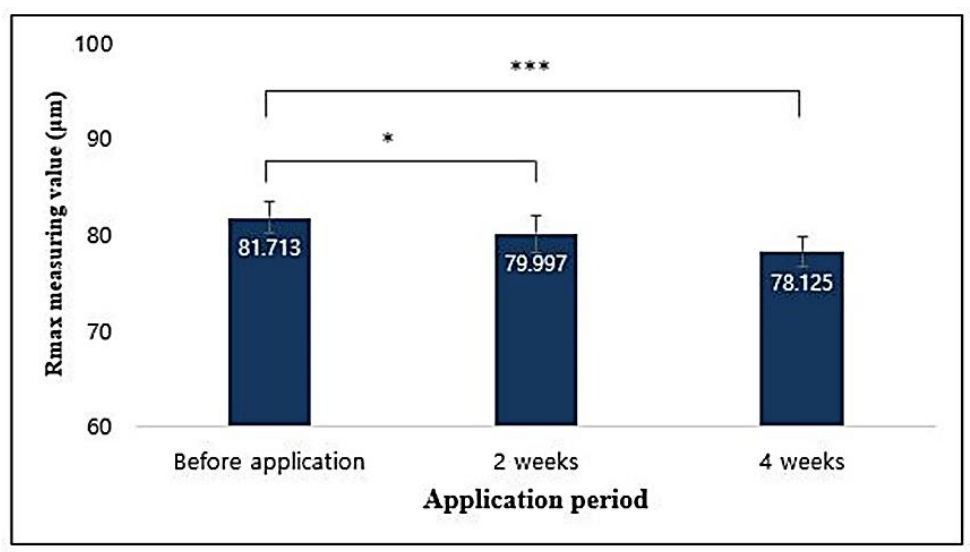

Figure 14. Correlation between application period of formulated cosmetics product and eye wrinkle roughness depth values (Rmax) analyzed using PRIMOS High Resolution. Data are given as mean \pm SEM and statistical significance is shown by ANOVA $\left({ }^{*} p<0.05 ;{ }^{* * *} p<0.001\right)$.

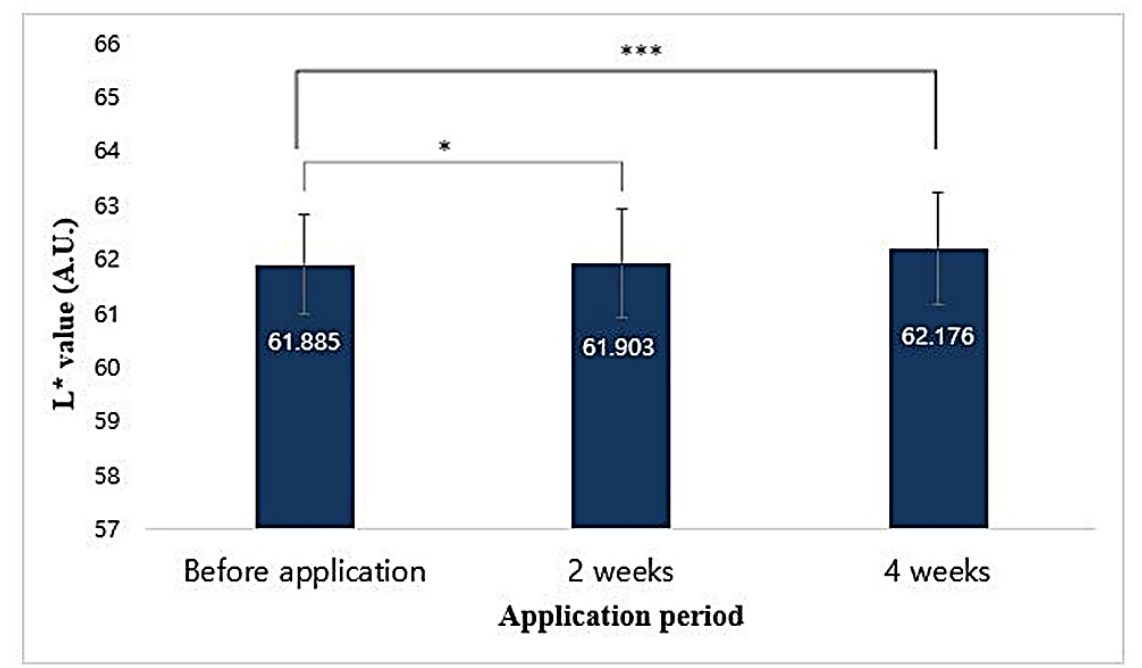

Figure 15. Correlation between application period of formulated cosmetics product and chromameter $\mathrm{L}^{*}$ values. Data are given as mean $\pm \mathrm{SEM}$ and statistical significance is shown by ANOVA $\left({ }^{*} p<0.05\right.$; $* * * p<0.001)$.

\section{Conclusions}

Secondary bioactive materials extracted from the soil microorganisms are of interest for cosmetic applications owing to their antimicrobial, antioxidant, anti-wrinkle, skin whitening, and antimicrobial activities. This study describes the novel activity of ethyl acetate extract of strain T65 culture for the functional ingredients in cosmetic formulations. The T65 crude product was non-toxic to the different cell lines, such as HaCaT (human keratinocyte), RAW264.7 (macrophage cell), CCD-986Sk (human skin fibroblast cell), and B16F1 and B16F10 melanoma cells. In addition, T65 crude product showed upregulation of collagen type I synthesis, which is very important for reducing wrinkles on the skin. Furthermore, T65 crude product sufficiently inhibited the human pathogenic bacteria such as $B$. subtilis, E. coli, P. acnes, S. aureus, and S. epidermidis, which may help to prevent spoilage of the cosmetic product and colonization of pathogenic bacteria forming acne vulgaris on human skin. Moreover, T65 crude product inhibited the mushroom tyrosinase for whitening effect and porcine pancreatic elastase for anti-aging activities, and inhibited NO and scavenged DPPH radicals for antioxidant activities. Synthesis of mesoporous silica particles, SBA-15, proved that the T65 crude product would be effective in the cosmeceutical formulations with effective controlled release properties. Finally, in vivo application of formulated cosmetic product along with T65 crude product on the faces of 
volunteers proved the whitening and anti-wrinkle effect of T65. However, the chemistry of different bioactive compounds and the molecular mechanisms related to the different enzyme inhibition and pathogen inhibition activities remain to be discovered. In conclusion, our study strongly supported the idea that bacterial resources can be added to topically applied cosmetic products for whitening effect, anti-wrinkle formation, anti-oxidant effect, and antimicrobial activities.

Supplementary Materials: The following are available online at http://www.mdpi.com/2076-3921/9/4/278/s1, Figure S1: Neighbor-joining tree based on 16S rRNA gene sequences showing the phylogenetic position of strain T65 among closely related members of the family Streptomycetaceae., Figure S2: Evaluation of cell toxicity in HaCaT human keratinocyte cell line, Figure S3: Zone of inhibition of T65 crude product against human pathogens, Figure S4: Analysis of particle size of SBA, Figure S5: HPLC chromatogram of T65 extract, Figure S6: HPLC data of T65 embedded SBA-15, Figure S7: Final product of aesthetic product formulated using T65 crude product, Figure S8: List of ingredients used in the formulation of cosmetic product, Table S1: Components of reaction mixtures for DPPH free radical scavenging assays, Table S2: Total reaction mixture for elastase inhibition assays, Table S3: Total reaction mixture for for tyrosinase inhibition assays, Table S4: List of bacterial strains having potential activities in cosmeceuticals, Table S5: DPPH free radical scavenging activities of T65 crude product, Table S6: Porcine pancreatic elastase (PPE) inhibition activities of T65 crude product, Table S7: Mushroom tyrosinase inhibition activities of T65 crude product, Table S8: Free amino acids from ethyl acetate extract of strain T65, Table S9: Composite amino acids from T65 ethyl acetate extract, Table S10: Fatty acids from ethyl acetate extract of strain T65, Table S11: Zone of inhibition of T65 crude extract from five different solvent systems, Table S12: Zone of inhibition of purified crude T65 compounds against gram-positive and gram-negative pathogens, Table S13: Determination of T65 immersion using BET analyses, Table S14: Stability of formulated cream in different conditions and temperatures.

Author Contributions: R.H.D., T.M.N., D.S.S., J.Y.K., and J.L. conceived, designed, and conducted all the experiments. D.S.S. was involved in tissue culture and cytotoxic activity for the sample. J.Y.K. and J.L. were involved in nanomaterial works and human trials. R.H.D. and J.Y.K. interpreted the data. J.K. coordinated and supervised the study. R.H.D., T.M.N., D.S.S., J.Y.K., and J.L. analyzed all the data and prepared the manuscript. All authors have read and agreed to the published version of the manuscript.

Funding: This study was supported by the Technological Innovation R\&D Program (S2392169) funded by the Small and Medium Business Administration (SMBA, Korea), and by the Basic Science Research Program through the National Research Foundation of Korea (NRF) (2019R1F1A1058501).

Conflicts of Interest: The authors declare that there is no conflict of interest regarding this manuscript. The funders had no role in the design of the study; in the collection, analyses, or interpretation of data; in the writing of the manuscript; or in the decision to publish the results.

\section{References}

1. Matts, P.J. New insights into skin appearance and measurement. J. Investig. Dermatology Symp. Proc. 2008, 13, 6-9. [CrossRef] [PubMed]

2. Fink, B.; Grammer, K.; Matts, P.J. Visible skin color distribution plays a role in the perception of age, attractiveness, and health in female faces. Evol. Hum. Behav. 2006, 27, 433-442. [CrossRef]

3. Jones, A.L.; Russell, R.; Ward, R. Cosmetics alter biologically-based factors of beauty: Evidence from facial contrast. Evol. Psychol. 2015, 13, 210-229. [CrossRef] [PubMed]

4. Jones, A.L.; Kramer, R.S.S. Facial cosmetics and attractiveness: Comparing the effect sizes of professionally-applied cosmetics and identity. PLoS ONE 2016, 11, 1-17. [CrossRef]

5. Taofiq, O.; Heleno, S.A.; Calhelha, R.C.; Alves, M.J.; Barros, L.; Barreiro, M.F.; González-Paramás, A.M.; Ferreira, I.C.F.R. Development of mushroom-based cosmeceutical formulations with anti-inflammatory, anti-tyrosinase, antioxidant, and antibacterial properties. Molecules 2016, 21, 1372. [CrossRef]

6. Ribeiro, A.; Estanqueiro, M.; Oliveira, M.; Sousa Lobo, J. Main benefits and applicability of plant extracts in skin care products. Cosmetics 2015, 2, 48-65. [CrossRef]

7. Farage, M.A.; Miller, K.W.; Elsner, P.; Maibach, H.I. Intrinsic and extrinsic factors in skin ageing: A review. Int. J. Cosmet. Sci. 2008, 30, 87-95. [CrossRef]

8. Krutmann, J.; Bouloc, A.; Sore, G.; Bernard, B.A.; Passeron, T. The skin aging exposome. J. Dermatol. Sci. 2017, 85, 152-161. [CrossRef] [PubMed]

9. Dahal, R.H.; Shim, D.S.; Kim, J. Development of actinobacterial resources for functional cosmetics. J. Cosmet. Dermatol. 2017, 16, 243-252. [CrossRef]

10. Long, A.; Crowther, J.; Beach, K.; Neil, J. Skin topometry changes demonstrate anti-aging efficacy of a topically applied cosmetic product via in vivo testing. J. Am. Acad. Dermatol. 2007, 56, 224. 
11. Ganceviciene, R.; Liakou, A.I.; Theodoridis, A.; Makrantonaki, E.; Zouboulis, C.C. Skin anti-aging strategies. Dermatoendocrinology 2012, 4, 308-319. [CrossRef]

12. Baxter, R.A. Anti-aging properties of resveratrol: Review and report of a potent new antioxidant skin care formulation. J. Cosmet. Dermatol. 2008, 7, 2-7. [CrossRef] [PubMed]

13. Mukherjee, S.; Date, A.; Patravale, V.; Korting, H.C.; Roeder, A.; Weindl, G. Retinoids in the treatment of skin aging: An overview of clinical efficacy and safety. Clin. Interv. Aging 2006, 1, 327-348. [CrossRef] [PubMed]

14. Fubini, B.; Hubbard, A. Reactive oxygen species (ROS) and reactive nitrogen species (RNS) generation by silica in inflammation and fibrosis. Free Radic. Biol. Med. 2003, 34, 1507-1516. [CrossRef]

15. Valko, M.; Leibfritz, D.; Moncol, J.; Cronin, M.T.D.; Mazur, M.; Telser, J. Free radicals and antioxidants in normal physiological functions and human disease. Int. J. Biochem. Cell Biol. 2007, 39, 44-84. [CrossRef] [PubMed]

16. Pham-Huy, L.A.; Hua, H.; Pham-Huy, C. Free radicals, antioxidants in disease and health. Int. J. Biomed. Sci. 2008, 4, 89-96. [PubMed]

17. Uttara, B.; Singh, A.V.; Zamboni, P.; Mahajan, R. Oxidative stress and neurodegenerative diseases: A review of upstream and downstream antioxidant therapeutic options. Curr. Neuropharmacol. 2009, 7, 65-74. [CrossRef]

18. Kurutas, E.B. The importance of antioxidants which play the role in cellular response against oxidative/nitrosative stress: Current state. Nutr. J. 2016, 15, 71. [CrossRef]

19. Fawole, O.A.; Makunga, N.P.; Opara, U.L. Antibacterial, antioxidant and tyrosinase-inhibition activities of pomegranate fruit peel methanolic extract. BMC Complement. Altern. Med. 2012, 12,1-11. [CrossRef]

20. Kim, M.; Shibata, T.; Kwon, S.; Park, T.J.; Kang, H.Y. Ultraviolet-irradiated endothelial cells secrete stem cell factor and induce epidermal pigmentation. Sci. Rep. 2018, 8, 4235. [CrossRef]

21. Hsu, K.D.; Chen, H.J.; Wang, C.S.; Lum, C.C.; Wu, S.P.; Lin, S.P.; Cheng, K.C. Extract of Ganoderma formosanum mycelium as a highly potent tyrosinase inhibitor. Sci. Rep. 2016, 6, 32854. [CrossRef] [PubMed]

22. Mondal, S.; Thampi, A.; Puranik, M. Kinetics of melanin polymerization during enzymatic and nonenzymatic oxidation. J. Phys. Chem. B 2018, 122, 2047-2063. [CrossRef] [PubMed]

23. Corinaldesi, C.; Barone, G.; Marcellini, F.; Dell'Anno, A.; Danovaro, R. Marine microbial-derived molecules and their potential use in cosmeceutical and cosmetic products. Mar. Drugs 2017, 15, 118. [CrossRef] [PubMed]

24. Lee, C.-M. Fifty years of research and development of cosmeceuticals: A contemporary review. J. Cosmet. Dermatol. 2016, 15, 527-539. [CrossRef]

25. Lee, J.; Ji, J.; Park, S.-H. Antiwrinkle and antimelanogenesis activity of the ethanol extracts of Lespedeza cuneata G. Don for development of the cosmeceutical ingredients. Food Sci. Nutr. 2018, 6, 1307-1316. [CrossRef]

26. Herman, A.; Herman, A.P.; Domagalska, B.W.; Młynarczyk, A. Essential oils and herbal extracts as antimicrobial agents in cosmetic emulsion. Indian J. Microbiol. 2013, 53, 232-237. [CrossRef]

27. Nabavi, S.F.; Di Lorenzo, A.; Izadi, M.; Sobarzo-Sánchez, E.; Daglia, M.; Nabavi, S.M. Antibacterial effects of cinnamon: From farm to food, cosmetic and pharmaceutical industries. Nutrients 2015, 7, 7729-7748. [CrossRef]

28. Klaschka, U. Natural personal care products-analysis of ingredient lists and legal situation. Environ. Sci. Eur. 2016, 28, 8. [CrossRef]

29. Alvarez-Rivera, G.; Llompart, M.; Lores, M.; Garcia-Jares, C. Preservatives in cosmetics: Regulatory aspects and analytical methods. Anal. Cosmet. Prod. 2018, 175-224.

30. Lee, L.H.; Chan, K.G.; Stach, J.; Wellington, E.M.H.; Goh, B.H. Editorial: The search for biological active agent(s) from actinobacteria. Front. Microbiol. 2018, 9, 824. [CrossRef]

31. Xu, R.; Shang, N.; Li, P. In vitro and in vivo antioxidant activity of exopolysaccharide fractions from Bifidobacterium animalis RH. Anaerobe 2011, 17, 226-231. [CrossRef] [PubMed]

32. Frank, J.A.; Reich, C.I.; Sharma, S.; Weisbaum, J.S.; Wilson, B.A.; Olsen, G.J. Critical evaluation of two primers commonly used for amplification of bacterial $16 \mathrm{~S}$ rRNA genes. Appl. Environ. Microbiol. 2008, 74, 2461-2470. [CrossRef] [PubMed]

33. Yoon, S.H.; Ha, S.M.; Kwon, S.; Lim, J.; Kim, Y.; Seo, H.; Chun, J. Introducing EzBioCloud: A taxonomically united database of $16 \mathrm{~S}$ rRNA gene sequences and whole-genome assemblies. Int. J. Syst. Evol. Microbiol. 2017, 67, 1613-1617. [CrossRef] [PubMed]

34. National Center for Biotechnology Information. Available online: https://www.ncbi.nlm.nih.gov/ (accessed on 25 March 2020).

35. Kumar, S.; Stecher, G.; Tamura, K. MEGA7: Molecular evolutionary genetics analysis version 7.0 for bigger datasets. Mol. Biol. Evol. 2016, 33, 1870-1874. [CrossRef] [PubMed] 
36. Shin, H.-M.; Byung, H.K.; Eun, Y.C.; Jung, S.-H.; Yeong, S.K.; Kyung, R.M.; Kim, Y. Suppressive effect of

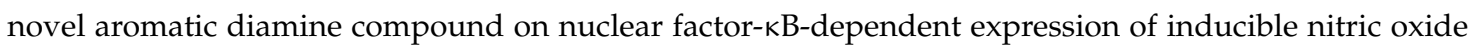
synthase in macrophages. Eur. J. Pharmacol. 2005, 521, 1-8. [CrossRef]

37. Zhao, D.; Huo, Q.; Feng, J.; Chmelka, B.F.; Stucky, G.D. Nonionic triblock and star diblock copolymer and oligomeric sufactant syntheses of highly ordered, hydrothermally stable, mesoporous silica structures. J. Am. Chem. Soc. 1998, 120, 6024-6036. [CrossRef]

38. Brightbill, H.D.; Modlin, R.L. Toll-like receptors: Molecular mechanisms of the mammalian immune response. Immunology 2000, 101, 1-10. [CrossRef]

39. Emre, Y.; Hurtaud, C.; Nübel, T.; Criscuolo, F.; Ricquier, D.; Cassard-Doulcier, A.-M. Mitochondria contribute to LPS-induced MAPK activation via uncoupling protein UCP2 in macrophages. Biochem. J. 2007, 402, 271-278. [CrossRef]

40. Sosroseno, W.; Barid, I.; Herminajeng, E.; Susilowati, H. Nitric oxide production by a murine macrophage cell line (RAW264.7) stimulated with lipopolysaccharide from Actinobacillus actinomycetemcomitans. Oral Microbiol. Immunol. 2002, 17, 72-78. [CrossRef]

41. Ahmed, S.; Sulaiman, S.A.; Baig, A.A.; Ibrahim, M.; Liaqat, S.; Fatima, S.; Jabeen, S.; Shamim, N.; Othman, N.H. Honey as a potential natural antioxidant medicine: An insight into its molecular mechanisms of action. Oxid. Med. Cell. Longev. 2018, 2018, 8367846. [CrossRef]

42. Padayatty, S.J.; Katz, A.; Wang, Y.; Eck, P.; Kwon, O.; Lee, J.-H.; Chen, S.; Corpe, C.; Dutta, A.; Dutta, S.K.; et al. Vitamin C as an antioxidant: Evaluation of its role in disease prevention. J. Am. Coll. Nutr. 2003, 22, 18-35. [CrossRef]

43. Pratt, D. Natural antioxidants from plant material. In ACS Symphosium Series, Vol. 507; American Chemical Society: Washington, DC, USA, 1992; pp. 54-71.

44. Kasote, D.M.; Katyare, S.S.; Hegde, M.V.; Bae, H. Significance of antioxidant potential of plants and its relevance to therapeutic applications. Int. J. Biol. Sci. 2015, 11, 982-991. [CrossRef]

45. Szymanska, R.; Pospisil, P.; Kruk, J. Plant-derived antioxidants in disease prevention. Oxid. Med. Cell. Longev. 2016, 2016, 1-2. [CrossRef]

46. Narsing Rao, M.P.; Xiao, M.; Li, W.-J. Fungal and bacterial pigments: Secondary metabolites with wide applications. Front. Microbiol. 2017, 8, 1113. [CrossRef]

47. Wang, Y.; Wu, Y.; Wang, Y.; Xu, H.; Mei, X.; Yu, D.; Wang, Y.; Li, W. Antioxidant properties of probiotic bacteria. Nutrients 2017, 9, 521. [CrossRef]

48. Ko, R.K.; Kim, G.-O.; Hyun, C.-G.; Jung, D.S.; Lee, N.H. Compounds with tyrosinase inhibition, elastase inhibition and DPPH radical scavenging activities from the branches of Distylium racemosum Sieb. et Zucc. Phyther. Res. 2011, 25, 1451-1456. [CrossRef]

49. Manivasagan, P.; Venkatesan, J.; Sivakumar, K.; Kim, S.-K. Pharmaceutically active secondary metabolites of marine actinobacteria. Microbiol. Res. 2014, 169, 262-278. [CrossRef] [PubMed]

50. You, J.; Roh, K.-B.; Li, Z.; Liu, G.; Tang, J.; Shin, S.; Park, D.; Jung, E.; You, J.; Roh, K.-B.; et al. The antiaging properties of andrographis paniculata by activation epidermal cell stemness. Molecules 2015, 20, 17557-17569. [CrossRef] [PubMed]

51. Oliver, N.; Sternlicht, M.; Gerritsen, K.; Goldschmeding, R. Could aging human skin use a connective tissue growth factor boost to increase collagen content? J. Investig. Dermatol. 2010, 130, 338-341. [CrossRef] [PubMed]

52. Murakami, H.; Shimbo, K.; Inoue, Y.; Takino, Y.; Kobayashi, H. Importance of amino acid composition to improve skin collagen protein synthesis rates in UV-irradiated mice. Amino Acids 2012, 42, 2481-2489. [CrossRef]

53. Burnett, C.L.; Heldreth, B.; Bergfeld, W.F.; Belsito, D.V.; Hill, R.A.; Klaassen, C.D.; Liebler, D.C.; Marks, J.G.; Shank, R.C.; Slaga, T.J.; et al. Safety assessment of $\alpha$-amino acids as used in cosmetics. Int. J. Toxicol. 2013, 32, 41S-64S. [CrossRef] [PubMed]

54. Aramwit, P.; Luplertlop, N.; Kanjanapruthipong, T.; Ampawong, S. Effect of urea-extracted sericin on melanogenesis: Potential applications in post-inflammatory hyperpigmentation. Biol. Res. 2018, 51. [CrossRef] [PubMed]

55. Marcuse, R. Antioxidative effect of amino-acids. Nature 1960, 186, 886-887. [CrossRef]

56. Canfield, C.-A.; Bradshaw, P.C. Amino acids in the regulation of aging and aging-related diseases. Transl. Med. Aging 2019, 3, 70-89. [CrossRef] 
57. Kubglomsong, S.; Theerakulkait, C.; Reed, R.L.; Yang, L.; Maier, C.S.; Stevens, J.F. Isolation and identification of tyrosinase-inhibitory and copper-chelating peptides from hydrolyzed rice-bran-derived albumin. J. Agric. Food Chem. 2018, 66, 8346-8354. [CrossRef] [PubMed]

58. Cha, J.Y.; Yang, H.J.; Moon, H.I.; Cho, Y.S. Branched-chain amino acids complex inhibits melanogenesis in B16F0 melanoma cells. Immunopharmacol. Immunotoxicol. 2012, 34, 256-264. [CrossRef]

59. Liu, D.Z.; Lin, Y.S.; Hou, W.C. Monohydroxamates of aspartic acid and glutamic acid exhibit antioxidant and angiotensin converting enzyme inhibitory activities. J. Agric. Food Chem. 2004, 52, 2386-2390. [CrossRef]

60. Tejpal, C.S.; Vijayagopal, P.; Elavarasan, K.; Linga Prabu, D.; Lekshmi, R.G.K.; Asha, K.K.; Anandan, R.; Chatterjee, N.S.; Mathew, S. Antioxidant, functional properties and amino acid composition of pepsin-derived protein hydrolysates from whole tilapia waste as influenced by pre-processing ice storage. J. Food Sci. Technol. 2017, 54, 4257-4267. [CrossRef]

61. Ali, H.M.; El-Gizawy, A.M.; El-Bassiouny, R.E.I.; Saleh, M.A. The role of various amino acids in enzymatic browning process in potato tubers, and identifying the browning products. Food Chem. 2016, 192, 879-885. [CrossRef]

62. Richard, D.; Kefi, K.; Barbe, U.; Bausero, P.; Visioli, F. Polyunsaturated fatty acids as antioxidants. Pharmacol. Res. 2008, 57, 451-455. [CrossRef]

63. Kumar, A.P.; Chougala, M.; Nandini, C.D.; Salimath, P.V. Effect of butyric acid supplementation on serum and renal antioxidant enzyme activities in streptozotocin-induced diabetic rats. J. Food Biochem. 2010, 34, 15-30. [CrossRef]

64. Gular, G.O. Studies on antioxidant properties of the different solvent extracts and fatty acid composition of Hyoscyamus reticulatus L. J. Food Biochem. 2012, 36, 532-538. [CrossRef]

65. Elagbar, Z.A.; Naik, R.R.; Shakya, A.K.; Bardaweel, S.K. Fatty acids analysis, antioxidant and biological activity of fixed oil of Annona muricata L. seeds. J. Chem. 2016, 2016. [CrossRef]

66. Aktumsek, A.; Zengin, G.; Guler, G.O.; Cakmak, Y.S.; Duran, A. Assessment of the antioxidant potential and fatty acid composition of four Centaurea L. taxa from Turkey. Food Chem. 2013, 141, 91-97. [CrossRef] [PubMed]

67. Nakatsuji, T.; Kao, M.C.; Fang, J.Y.; Zouboulis, C.C.; Zhang, L.; Gallo, R.L.; Huang, C.M. Antimicrobial property of lauric acid against Propionibacterium acnes: Its therapeutic potential for inflammatory acne vulgaris. J. Invest. Dermatol. 2009, 129, 2480-2488. [CrossRef]

68. Otto, M. Staphylococcus colonization of the skin and antimicrobial peptides. Expert Rev. Dermatol. 2010, 5, 183-195. [CrossRef]

69. Yanagisawa, T.; Shimizu, T.; Kuroda, K.; Kato, C. The preparation of alkyltriinethylaininonium-kaneinite complexes and their conversion to microporous materials. Bull. Chem. Soc. Jpn. 1990, 63, 988-992. [CrossRef]

70. Beck, J.S.; Vartuli, J.C.; Roth, W.J.; Leonowicz, M.E.; Kresge, C.T.; Schmitt, K.D.; Chu, C.T.W.; Olson, D.H.; Sheppard, E.W.; McCullen, S.B.; et al. A new family of mesoporous molecular sieves prepared with liquid crystal templates. J. Am. Chem. Soc. 1992, 114, 10834-10843. [CrossRef]

71. Trewyn, B.G.; Slowing, I.I.; Giri, S.; Chen, H.T.; Lin, V.S.Y. Synthesis and functionalization of a mesoporous silica nanoparticle based on the sol-gel process and applications in controlled release. Acc. Chem. Res. 2007, 40, 846-853. [CrossRef]

72. Zhao, D.; Feng, J.; Huo, Q.; Melosh, N.; Fredrickson, G.H.; Chmelka, B.F.; Stucky, G.D. Triblock copolymer syntheses of mesoporous silica with periodic 50 to 300 angstrom pores. Science 1998, 279, 548-552. [CrossRef]

73. Da Silva, L.S.; Moretti, A.L.; Cher, G.G.; Arroyo, P.A. Influence of crystallization and ageing time on the reproducibility of mesoporous molecular sieve SBA-15. Rev. Mater. 2019, 24. [CrossRef]

74. Knežević, N.; Durand, J.O. Large pore mesoporous silica nanomaterials for application in delivery of biomolecules. Nanoscale 2015, 7, 2199-2209. [CrossRef] [PubMed]

75. Ojeda, M.L.; Esparza, J.M.; Campero, A.; Cordero, S.; Kornhauser, I.; Rojas, F. On comparing BJH and NLDFT pore-size distributions determined from $\mathrm{N}_{2}$ sorption on SBA-15 substrata. Phys. Chem. Chem. Phys. 2003, 5, 1859-1866. [CrossRef]

(C) 2020 by the authors. Licensee MDPI, Basel, Switzerland. This article is an open access article distributed under the terms and conditions of the Creative Commons Attribution (CC BY) license (http://creativecommons.org/licenses/by/4.0/). 